\title{
My Brother's Keeper: An Empirical Study of Attorney Facilitation of Money-Laundering through Commercial Transactions
}

\author{
Lawton P. Cummings ${ }^{1}$ and Paul T. Stepnowsky ${ }^{2}$
}

\begin{abstract}
In recent years, various "gatekeeping initiatives" have been introduced through inter-governmental standard-setting organizations, such as the Financial Action Task Force, as well as through federal legislation in the United States, which seek to apply the mandatory customer due diligence, record keeping, and suspicious activity reporting obligations contained in the existing anti-money laundering regime to lawyers when they conduct certain commercial transactions on behalf of their clients. The organized bar has argued against such attempts to regulate it, in part, due to the lack of empirical data showing that, as a threshold matter, lawyers unwittingly aid money laundering in a significant number of cases. Through the analysis of a sample of money laundering cases from the Second Circuit, this Article empirically examines whether lawyers are involved knowingly or unknowingly in transactions that serve to launder illicit funds, and it considers the implications of the study on whether lawyers should serve as gate-keepers against money-laundering.
\end{abstract}

\section{Introduction}

On February 4, 2010, the United States Senate Permanent Subcommittee on Investigations held Hearings on "Keeping Foreign Corruption Out of the United States" and issued a report with the same title, which detailed four case studies in which United States banks and professionals facilitated transactions that laundered money for foreign

\footnotetext{
${ }^{1}$ Visiting Associate Professor of Law, The University of Maryland School of Law. This paper was presented at the Fourth International Legal Ethics Conference at Stanford Law School, and at the Southeastern Association of Law Schools Annual Meeting. Data compiled and used in the study are available upon request from the author. I would like to thank Professors Robert W. Tuttle, Thomas D. Morgan, Stephen A. Saltzburg, and Donald Braman, who provided valuable insights and comments on prior drafts of this article. I would also like to thank Dean Fred Lawrence of the George Washington University Law School for his generous research support when I was a Visiting Associate Professor of Law there, as well as my outstanding George Washington law student and fellow research assistants, Kathryn Moss, Jennifer Yeh, and Eduardo Martinez.

2 J.D. 2010, The George Washington University Law School. Law Clerk to the Honorable Roger Titus, United States District Court for the District of Maryland, commencing August 2011. I would like to thank Mark Taticchi for his helpful comments and Dana Parsons for her continued support.
} 
corrupt officials and their families. ${ }^{3}$ One of the cases involved Teodoro Obiang, the son of the President of Equatorial Guinea, who used his lawyer's services to launder over \$110 million in illicit funds through the lawyer's client trust account and through accounts belonging to various shell ${ }^{4}$ companies. ${ }^{5}$ The Subcommittee used its findings from the Hearing and the Report to support pending legislation and rule-making by the United States Treasury (“Treasury”) that may impose federal regulations on United States attorneys, which would require transactional attorneys, as so-called "gate-keepers to the financial system" ${ }^{6}$ to engage in customer due diligence, record-keeping, and reporting of suspicious activities by their clients.

\footnotetext{
${ }^{3}$ See United States Senate, Permanent Subcomm. On InVestigations, KeEPing Foreign CORRUPTION OUT OF THE UNITED STATES: FOUR CASE HISTORIES, (February 2010), available at http://levin.senate.gov/newsroom/release.cfm?id=322088.; see also Int'l Bar Assoc., Anti-Money Laundering Forum, Report from the U.S. Senate's permanent Subcommittee on Investigations brings back the debate on lawyers and money laundering (May 2010), available at http://www.antimoneylaundering.org/News_2010_1.aspx\#05022010.

${ }^{4}$ Shell companies are typically defined as a "non-publicly traded corporation, limited liability companies, and trusts that typically have no physical presence (other than a mailing address) and generate little to no independent economic value." See DEPT. OF THE TREASURY, FIN. CRIMES ENFORCEMENT NETWORK, POTENTIAL MONEY LAUNDERING RISKS RELATED TO SHELl COMPANIES (November 2006), available at http://www.fincen.gov/statutes_regs/guidance/pdf/AdvisoryOnShells_FINAL.pdf.

${ }^{5}$ See Keeping Foreign Corruption Out of the United States: Four Case Histories, Hearing Before the S. Comm. on Homeland Security and Government Affairs, (2010) (statement of James H. Fries, Jr., Director, Financial Crimes Enforcement Network, United States Dep't of the Treasury), available at http://levin.senate.gov/newsroom/release.cfm?id=322088. ; See also Int'1 Bar Assoc., Anti-Money Laundering Forum, Report from the U.S. Senate's permanent Subcommittee on Investigations brings back the debate on lawyers and money laundering (May 2010), available at http://www.antimoneylaundering.org/News_2010_1.aspx\#05022010.
}

6 "The theory underlying gatekeeper liability is that civil or criminal liability can induce outsiders who are firm participants (such as . . lawyers. . .) to discover and prevent offenses of the [client]. Moreover, [] the thought is that the gatekeeper outsiders to the transaction pledge their reputational capital to provide assurance to the investors of the integrity of the transaction." J. Dzienkowski \& R. Peroni, The Decline in Lawyer Independence: Lawyer Equity Investments in Clients, 81 TEX. L. REV. 405, 481 (2002). For an overview of gatekeeper theory in the context of lawyer regulation, see Lawrence Cunningham, Beyond Liability: Rewarding Effective Gatekeepers, 92 MinN. L. REV. 323 (2007); John Coffee, Jr., The Attorney as Gatekeeper: An Agenda for the SEC, 103 COLUM. L. REV. 1293 (2003). Federal gate-keeping regulations have been applied to lawyers in other contexts. See, e.g., Sarbanes-Oxley Act of 2002, Section 15 U.S. C. et. Seq. and 17 C.F.R. section 205.2 (a)(1); 31 C.F.R. section 10.3 (2002); 31 USC Section 5331 and IRC, Section 6050I (Requiring currency transaction reporting). For a discussion of these regulations as they apply to lawyers, see Thomas D. Morgan, Comment on Lawyers as Gatekeepers, 57 CASE W. RES. L. 
In recent years, intergovernmental standard-setting organizations have sought to draft lawyers as "gatekeepers" ${ }^{7}$ of the financial system by imposing various mandatory responsibilities on them. Chief among these are customer due diligence (e.g., verifying client identity, employment, and other basic information relevant to the service the lawyer is engaged to perform), recordkeeping, and the duty to report suspicious activity to government authorities if attorneys conduct certain commercial transactions on behalf of their clients. ${ }^{8}$ The organization spearheading this movement is the Financial Action Task Force ("FATF"). The FATF is an international body comprised of various member countries with the mandate to coordinate anti-money laundering efforts at both national and international levels. The organized bar has argued against such attempts to regulate it, in part, due to the lack of empirical data showing that, as a threshold matter, lawyers unwittingly aid money laundering in a significant number of cases. ${ }^{11}$

REV. 375 (2007); Laurel S. Terry, The Future Regulation of the Legal Profession: The Impact of Treating the Legal Profession as "Service Providers," 2008 J. PROF'L LAWYER 189 (2008); Fred Zacharias, Lawyers as Gatekeepers, 41 SAN DIEGo L. REV. 1387 (2004); Coffee, supra; Roger C. Cramton, et al., Legal and Ethical Duties of Lawyers After Sarbanes-Oxley, 49 VILL. L. REV. 725, 741-46 (2004); Ellen S. Podgor, Form 8300: The Demise of Law as a Profession, GeO. J. Legal Ethics 485 (1992).

${ }^{7}$ The term "gatekeeper" is used in this context to describe the relationship of the lawyer to the financial system. As the FATF explains, "If one looks at the types of assistance that these professionals may provide, it is apparent that some of these functions are the gateway through which the launderer must pass to achieve his goals. Thus the legal and accounting professionals serve as a sort of "gatekeeper" since they have the ability to furnish access (knowingly or unwittingly) to the various functions that might help the criminal with funds to move or conceal." FIN. ACTION TASK FORCE, REPORT ON MONEY LAUNDERING TYPOLOGIES 12 (Feb. 2001), available at http://www.fatf-gafi.org/dataoecd/29/36/34038090.pdf.

${ }^{8}$ See Kevin L. Shepherd, Guardians at the Gate: the Gatekeeper Initiative and the Risk-Based Approach for Transactional Lawyers, 43 REAL PROP. TRUST \& ESTATE L. J. 607 (2009) (discussing the FATF Gatekeeper initiative, as well as various federal bills intended to implement those Recommendations); FATF Revised 40+9 and Lawyer Guidance; see also S.569 Incorporation Transparency and Law Enforcement Assistance Act, 1 S.569 (2009) and S. 2956 (2008); Stop Tax Haven Abuse Act, S. 506 and H.R. 1265 (2009), S. 681, $110^{\text {th }}$ Cong. (2007).

${ }^{11}$ Am. Bar Assoc., Task Force on GateKeEPer Regulation AND the Profession, RePORT ACCOMPANYING EXEC SUMM. RES. 300, 7 (2008), available at http://www.abanet.org/leadership/2008/annual/recommendations/ThreeHundred.doc.(asserting that "[i]t is evident that insufficient information has been obtained and analysis conducted to determine the relative costs and benefits of any STR requirement for the legal profession," and that "there is no indication that the 
This Article contributes to the consideration of whether lawyers are in a position to serve as gatekeepers against money laundering by empirically examining whether lawyers are involved in transactions that serve to launder elicit funds. To that end, this Article contains an analysis of a sample of money laundering cases from the Second Circuit that indicates typologies for unwitting attorney facilitation of transactions employed to launder illicit funds. Of the forty cases included in the final data set of this study, ten cases presented evidence of some level of lawyer involvement in the transaction employed to launder the illicit funds. Six cases contained evidence of nonself directed lawyer involvement in the transactions employed to launder the illicit funds. This article analyzes the Second Circuit data to determine the merits of gatekeeping regulation for attorneys.

Part II of this Article provides a background of the multinational anti-money laundering regime and situates the various attorney gatekeeper initiatives within that regulatory framework. Part III describes the empirical study that was the basis of this Article. Part IV considers the implications of the study on whether lawyers are in a position to serve as gatekeepers against money laundering. It concludes that the $\mathrm{ABA}$ should require that a lawyer certify that she reasonably believes that the client does not present a risk of abusing the lawyer's services to launder money under risk-based guidelines maintained in the ABA Good Practices. This proposal attempts to strike a

U.S. government has undertaken any meaningful examination, consideration, or cost-benefit analysis of these issues. . . At a minimum, this should be done before the U.S. government formulates any policy on the Gatekeeper Initiative."). See also Neil Rose, Making the Case for Appropriate Anti-Money Laundering Rules for Lawyers, INT'L BAR NEws, 37-39, April 2009, available at http://www.antimoneylaundering.org/AMLResources.aspx\#FeArticles (interview with Stephen Revell, Chair of the International Bar Association (IBA) Anti-Money Laundering Legislation Implementation Group, who explained that the IBA has strongly requested such data from the FATF, explaining that the FATF has not provided any data regarding whether lawyers are unwittingly involved in transactions that facilitate money laundering, which he claims is needed in order to justify the AML gatekeeping regulation of lawyers). 
balance between Congressional concern that federal regulation is necessary for FATF compliance and the ABA's current voluntary approach to due diligence requirements.

\section{Background of the Gatekeeping Initiatives within the Multinational Anti- Money Laundering Regime}

This Section first describes the multinational anti-money laundering regime. It then describes the FATF's Gatekeeper Initiative, including the development of money laundering concerns tied to terrorism in the post-September 11th world. Finally, it investigates the practical and political consequences of the FATF's regime on lawyers in the United States and the international community. Importantly, this Section describes the ABA's resistance to federal Gatekeeper regulation, and the ABA's creation of the Good Practices Guidance to educate lawyers on client risk-assessment, while incorporating the FATF's risk-based approach to client due diligence.

\section{A. Overview of the Anti-Money Laundering Regime}

Money laundering 'is the criminal practice of filtering ill-gotten gains, or 'dirty' money, through a series of transactions; in this way the funds are 'cleaned' so that they appear to be proceeds from legal activities. ${ }^{13}$ In order to use the proceeds of their crime without triggering suspicion, criminals attempt to obscure the criminal source of the funds through financial transactions, which would generally not be illegal in and of themselves, but are criminalized ${ }^{14}$ as money laundering because the purpose of the

\footnotetext{
${ }^{13}$ FeD. Fin. InSTS. EXAMINATION COUNCIL, BANK SECRECY ACt ANTI-MONEy LAUNDERING EXAMINATION MANUAL, 14, (June 2005), available at www.occ.treas.gov/handbook/BSAAMLexamprocedures.pdf.

${ }^{14}$ Penalties for money laundering can be severe. Individuals convicted of money laundering face up to twenty years in prison for each money laundering transaction as well as fines up to the greater of $\$ 500,000$ or twice the value of the transaction. See Mark Motivans, Money Laundering Offenders 1994-2001, July 2003, available at http://bjs.ojp.usdoj.gov/index.cfm?ty=pbdetail\&iid=790; 18 USC $\S$ 1956, 1957 (2006). In addition, any property involved in the transaction or traceable to the proceeds of the criminal activity, including loan collateral, personal property and, under certain conditions, entire bank accounts (even if
} 
transactions is to conceal the source of the funds. Money laundering generally consist of three sequential financial transactions: (1) placement of funds derived from an illegal activity "to a place or into a form that is less suspicious to law enforcement, [such as] traditional or nontraditional financial institutions;" (2) layering of those funds in order to separate the funds from the criminal activity by "using multiple complex financial transactions (e.g., wire transfers, monetary instruments) to obscure the audit trail and hide the proceeds;" and (3) integration of the funds into the economy "through normal financial or commercial operations where they appear to be legitimate." ${ }^{\prime 15}$

The International Monetary Fund ("IMF") estimates that money laundering in a single year accounts for "between two and five percent of global gross domestic product, [which] amounts to hundreds of billions, and possibly trillions, of dollars in criminal proceeds that are annually laundered through the banking system." ${ }^{\prime 16}$ The transactions used to launder the money would be legal, if the money were not derived from criminal activity. Therefore, the crime of money laundering is aimed at deterring the predicate crimes, as well as protecting the financial system from abuse. ${ }^{17}$

Congress first criminalized money laundering in $1986^{18}$ as part of the "war on drugs," in an effort to choke off and seize the flow of money that would otherwise be

some of the money in the account is legitimate) may be subject to forfeiture. See 31 U.S.C. $\S$ 5317(c)(1)(B)(2006).

${ }^{15}$ Peter Reuter \& Edwin M. Truman, Chasing Dirty Money: The Fight Against Money

LAUNDERING 25 (2004) (quoting a report by the Board of Governors of the Federal Reserve System (2002).

${ }^{16}$ Rebecca Gregory, The Lawyer's Role: Will Uncle Sam Want You in the Fight Against Money Laundering and Terrorism?" 72 UMKC L. Rev. 23, 26 (2003) (quoting FATF Basic Facts about Money Laundering, available at www.oecd.org/fatf).

${ }^{17}$ REUTER \& TRUMAN, supra note 15 , at 25 .

${ }^{18}$ Money laundering was made a federal crime under the Money Laundering Control Act of 1986 and is addressed under 18 U.S.C. $§ 1956$ (laundering of monetary instruments) and $§ 1957$ (engaging in monetary transactions in property derived from specified unlawful activity). 18 U.S.C. § 1956(a)(1) imposes a 
reinvested in drug trafficking by money launderers. ${ }^{19}$ Since that time, the list of predicate crimes has grown to over 150 offenses, which include most crimes that generate illicit funds, including fraud and other financial, so called "white collar" crimes, illegal gambling, and insurance fraud. ${ }^{20}$

Following the September 11, 2001 attacks on the United States, Congress added combating the financing of terrorism as one of the primary goals of the money-laundering statutes. $^{21}$ While the transactions used to launder money and those used to finance terrorism are the same transactions used by other types of criminals to launder illicit

criminal penalty upon any person who knowing that the property involved in a financial transaction represents the proceeds of some form of unlawful activity, conducts or attempts to conduct such a financial transaction which in fact involves the proceeds of specified unlawful activity (A) (i) with the intent to promote the carrying on of specified unlawful activity; or (ii) with intent to engage in conduct constituting a violation of section 7201 or 7206 of the Internal Revenue Code of 1986; or (B) knowing that the transaction is designed in whole or in part (i) to conceal or disguise the nature, the location, the source, the ownership, or the control of the proceeds of specified unlawful activity; or (ii) to avoid a transaction reporting requirement under State or Federal Law.

18 U.S.C. $§ 1956$ (a). Section 1956(a) further imposes a criminal penalty upon any person who transports, transmits, or transfers, or attempts to transport, transmit, or transfer a monetary instrument or funds from a place in the United States to or through a place outside the United States or to a place in the United States from or through a place outside the United States (A) with the intent to promote the carrying on of specified unlawful activity; or (B) knowing that the monetary instrument or funds involved in the transportation, transmission, or transfer represent the proceeds of some form of unlawful activity and knowing that such transportation, transmission, or transfer is designed in whole or in part (i) to conceal or disguise the nature, the location, the source, the ownership, or the control of the proceeds of specified unlawful activity; or (ii) to avoid a transaction reporting requirement under State or Federal law."

Id. Section 1957 of Title 18, United States Code, provides, in pertinent part, that "[w]hoever ... knowingly engages or attempts to engage in a monetary transaction in criminally derived property that is of a value greater than $\$ 10,000$ and is derived from specified unlawful activity" shall be guilty of a crime. A "monetary transaction" includes "the deposit, withdrawal, transfer, or exchange, in or affecting interstate or foreign commerce, of funds or a monetary instrument ... by, through, or to a financial institution..." 18 U.S.C. Section 1957(f)(1). Section 1956(b) provides a forfeiture mechanism for money and property that is related to the money laundering scheme.

${ }^{19}$ REUTER \& TRUMAN, supra note 15 , at 64.

${ }^{20}$ See 18 USC 1956 list of predicate crimes; REUTER \& TRUMAN, supra note 15, at 66.

${ }^{21}$ Richard M. STANA, Dir. Homeland SEC. AND Justice IsSUES, Gov’t ACCOUNTABILITY OfFice, INVESTIGATING MONEY LAUNDERING AND TERRORIST FINANCING: FEDERAL LAW ENFORCEMENT AGENCIES FACE CONTINUED COORDINATION CHALLENGES (2004), available at http://www.gao.gov/new.items/d04710t.pdf; REUTER \& TRUMAN, supra note 15, at 139-50. 
proceeds, the financing of terrorism can differ in that the money may not be derived from criminal proceeds in the first instance. In other words, while some money used to finance terrorism may come from illicit sources, such as drug trafficking, ${ }^{22}$ other sources may include legal activities. In the latter case, the money only becomes tainted after the transaction, rather than the reverse order. However, law enforcement employs the same detection mechanisms in instances to identify money that is tainted due to its illicit source and to identify money that may be used to finance terrorism. Therefore, the anti-money laundering and countering of the financing of terrorism prevention efforts are combined under one anti-money laundering (“AML”) regime.

The centerpiece of the United States' prevention pillar of its AML effort is the Bank Secrecy Act, as amended by the Patriot Act. ${ }^{23}$ Adhering to the adage to 'follow the money' to investigate crimes that generate proceeds, the Bank Secrecy Act, as amended by the USA Patriot Act, requires "financial institutions" in the United States to: 1) engage in customer due diligence $;^{24}$ 2) maintain records regarding certain customer

\footnotetext{
${ }^{22}$ For example, "according to the US Drug Enforcement Administration, nineteen of the forty-three designated foreign terrorist organizations are linked definitively to the global drug trade, and up to sixty percent of terrorist organizations are connected in some way with the illegal drug trade." Matthew Levitt \& Michael Jacobson, The Money Trail: Finding, Following, and Freezing Terrorist Finances, The Washington Institute for Near East Policy, Policy Focus \#89, 10 (November 2008), available at http://98.129.103.82/index.php/learn/recent-news/10-newsmaster/549-the-money-trail-finding-followingand-freezing-terrorist-finance-.

${ }^{23}$ Uniting and Strengthening America by Providing Appropriate Tools Required to Intercept and Obstruct Terrorism (USA PATRIOT) Act of 2001, Pub. L. No. 107-56, 115 Stat. 272 (2001) [hereinafter "Patriot Act"]; see also REUTER \& TRUMAN, supra note 15, at 65.

${ }^{24}$ Under the Bank Secrecy Act, financial institutions are required to engage in customer due diligence through which "the organization (1) assesses the risks associated with a customer account or transaction, and (2) gathers sufficient information to evaluate whether a particular transaction warrants the filing of a SAR." The Bank Secrecy Act and the US Patriot Act, Hearing Before the H. Comm. on International Relations, (2004) (statement of Herbert A. Biern, Senior Associate Director, Division of Banking Supervision and Regulation, Federal Reserve), available at http://www.federalreserve.gov/boarddocs/testimony/2004/20041117/default.htm. As part of this customer due diligence, each financial institutions must implement a "Customer Identification Program, which includes account-opening procedures that specify the identifying information that will be obtained from
} 
transactions; ${ }^{25}$ and 3 ) comply with federal reporting requirements, including submitting a currency transaction report ("CTR") ${ }^{26}$ to the Treasury Department's Financial Crimes Enforcement Network ("FinCEN") or Internal Revenue Service ("IRS") 27 for any cash transaction involving $\$ 10,000$ or more, and submitting a suspicious activity report $(\text { ("SAR") })^{28}$ to FinCEN to report suspicious activity that may indicate money laundering. ${ }^{29}$

each customer, and which include reasonable and practical risk-based procedures for verifying the customer's identity. These procedures must enable the institution to form a reasonable belief that it knows the true identity of each customer." Id.

${ }^{25}$ The BSA regulations require financial institutions to maintain certain records for a period of five years to ensure that law enforcement may reconstruct the trail of money. Two such records financial institutions must maintain are 1) each cash sale of bank checks, drafts, cashier's checks, money orders, and traveler's checks between $\$ 3,000$ and $\$ 10,000$, including evidence of verification of the identity of the purchaser, 31 CFR 103.29; and 2) a record of each funds transfer of $\$ 3,000$ or more which it originates, acts as an intermediary for, or receives (31 CFR103.33 (e) and (g)).

${ }^{26}$ See 31 U.S.C. $\$ 5331$ and IRC $\$$ 6050I. These provisions require that a CTR (Form 8300) must be filed with the Internal Revenue Service or FinCEN for each deposit, withdrawal, exchange of currency, or other payment or transfer, by, through or to a financial institution, which involves a transaction in currency of more than \$10,000). Multiple currency transactions must be treated as a single transaction if the financial institution has knowledge that: (a) they are conducted by or on behalf of the same person; and, (b) they result in cash received or disbursed by the financial institution of more than $\$ 10,000$. See 31 CFR 103.22.

${ }^{27}$ See 31 USC $\$ \S 5311-30$ and 31 CFR 103.

${ }^{28}$ Covered financial institutions must file a Treasury Department Form 90-22.47 and OCC Form 8010-9, 8010-1 Suspicious Activity Report (SAR) for any suspicious transaction relevant to a possible violation of law or regulation. 31 CFR 103.18;12 CFR 12.11. Guidelines for identifying suspicious activities can be found in the Comptroller of the Currency's Bank Secrecy Act/Anti-Money Laundering Handbook, available at http://www.occ.treas.gov/handbook/bsa.pdf.

${ }^{29}$ Suspicious activity reports have replaced currency transaction reports as the primary source of information from financial institutions to law enforcement in the anti-money laundering regime. See REUTER \& TRUMAN, supra note 15, at 106. The voluminous number of CTRs filed each year restricts their utility. See, e.g., Courtney Linn, Redefining the Bank Secrecy Act: Currency Reporting and the Crime of Structuring, 50 SANTA CLARA L. REV. 407 (2010) (explaining over 16,000,000 CTR filings by financial institutions in the 2007-2009 fiscal year) (citing Financial Crimes Enforcement Network, U.S. Dep't of the Treasury, Fiscal Year 2008 Annual Report 6 (2008)). In contrast, a fraction of the number of SARs are filed each year, and the ratio of SARs filed to open law enforcement investigations is much higher. In the eight-year period between April 1, 1996 and June 30, 2004, 1,450,000 SARs were filed. See U.S. Treasury Department, U.S. Money Laundering Threat Assessment, National Money Laundering Strategy App. A (2007), available at http://www.ustreas.gov/press/releases/docs/nmls.pdf.; REUTER \& TRUMAN, supra note 15 , at 106 ("For the $61 / 2$ period ending October 31, 2002, 940,000 SARs produced 70,000 direct referrals to federal law enforcement agencies, of which half were the FBI."); Matthew Levitt \& Michael Jacobson, The Money Trail: Finding, Following, and Freezing Terrorist Finances, The Washington Institute for Near East Policy, Policy Focus \#89, 20 (November 2008), available at http://98.129.103.82/index.php/learn/recentnews/10-newsmaster/549-the-money-trail-finding-following-and-freezing-terrorist-finance-. (reporting that "about a 20 percent correlation between SARs and open FBI investigations."). 
The Federal Reserve ${ }^{30}$ conducts on-site investigations to monitor financial institutions' compliance. ${ }^{31}$ Institutions that are found to be non-compliant with the Bank Secrecy Act's requirements can be subject civil and criminal penalties. ${ }^{32}$

The United States expanded its AML effort to include an effort to encourage other jurisdictions to adopt provisions modeled after the Bank Secrecy Act in their own AML regimes. ${ }^{33}$ At the G-7 Summit in Paris in 1989, the United States and France proposed an initiative which led to the formation of the Financial Action Task Force on Money Laundering, an intergovernmental body ${ }^{34}$ with its Secretariat housed at the Orgarnisation for Economic Co-Operation and Development in France, with the mandate to coordinate AML efforts "at a national and international level, and setting out the measures that still needed to be taken to combat money laundering." ${ }^{35}$ In 1990, the FATF issued Forty Recommendations, a report recommending AML measures to be taken by each member

\footnotetext{
${ }^{30}$ The Treasury has statutory authority to administer the Bank Secrecy Act, and it has delegated this authority to its Financial Crimes division, FinCEN. FinCEN promulgates regulations and guidance to the regulated industries. FinCEN has delegated its authority to examine institutions for compliance with the BSA to the Federal Reserve. The Bank Secrecy Act and the US Patriot Act, Hearing Before the H. Comm. on International Relations, (2004) (statement of Herbert A. Biern, Senior Associate Director, Division of Banking Supervision and Regulation, Federal Reserve), available at http://www.federalreserve.gov/boarddocs/testimony/2004/20041117/default.htm.

${ }^{31}$ Comptroller of the Currency, Bank Secrecy Act/Anti-Money Laundering Handbook (2000), available at http://www.occ.treas.gov/handbook/bsa.pdf;. The Bank Secrecy Act and the US Patriot Act, Hearing Before the H. Comm. on International Relations, (2004) (statement of Herbert A. Biern, Senior Associate Director, Division of Banking Supervision and Regulation, Federal Reserve), available at http://www.federalreserve.gov/boarddocs/testimony/2004/20041117/default.htm

${ }^{32}$ See 31 U.S.C.5321; REUTER \& TRUMAN, supra note 15, at 55.

${ }^{33}$ REUTER \& TRUMAN, supra note 15, at 79. A Treasury Department official leads the United States delegation to FATF. See LOREn YAGER, ET AL, Government ACCOUnTABILITy OfFice, COMBATING ILLICIT FINANCING: TREASURY'S OFFICE OF TERRORISM AND FINANCIAL INTELLIGENCE COULD MANAGE MORE EFFECTIVELY TO ACHIEVE ITS Mission (2009), available athttp://www.gao.gov/new.items/d09794.pdf.

${ }^{34}$ The FATF now consists of 34 member States, as well as numerous observer States. See Financial Action

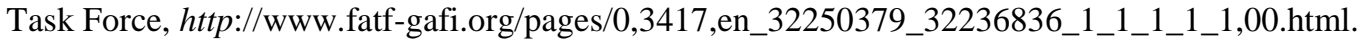

${ }^{35} I d$.
} 
nation. ${ }^{36}$ Following the September 11, 2001 attacks, the fight against terrorist financing was added to the FATF's mission, and the FATF issued nine special recommendations aimed at countering the financing of terrorism. ${ }^{37}$ The FATF now consists of thirty-four member nations, which comprise the major financial centers of the world. ${ }^{38}$

The FATF's recommendations are "soft law," as opposed to "hard law," because its recommendations are not directly legally binding on participants. ${ }^{39}$ The FATF, however, has been successful in advancing its standards throughout the globe. ${ }^{40}$ The FATF's success is due in part to the global governance system that has evolved in our current world, which is marked by globalization and interdependence. In recent years, international standard setting for financial markets has evolved from a system made up primarily of state actors who form multinational treaties and the resulting international treaty-sanctioned organizations, such as the World Bank and the IMF, to a system of "global governance."41 This includes "networks of domestic regulators that develop and

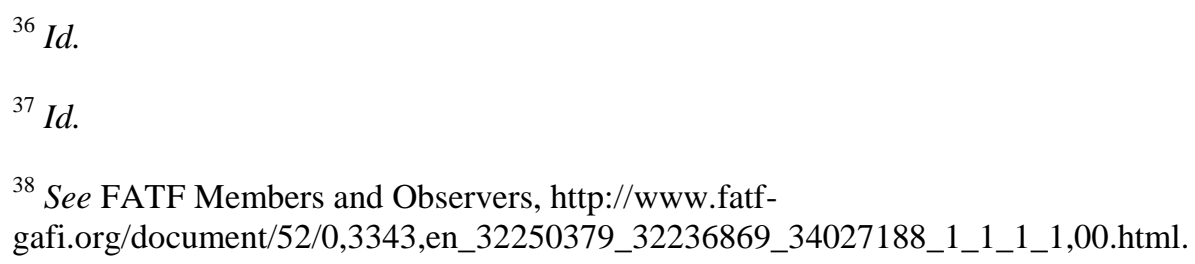

${ }^{39}$ The precise definitions of soft law and hard law vary among scholars. Legal positivists tend to discuss hard and soft law in binary terms, based on whether or not the law is binding, while rationalists consider hard and soft law attributes that can be chosen in different contexts. For a discussion of hard and soft international law, see Gregory C. Shaffer \& Mark A. Pollack, Hard vs. Soft Law: Alternatives, Complements, and Antagonists in International Governance, 94 MINN. L. REV. 706 (2010).

${ }^{40}$ The Forty Recommendations have been adopted by at least 130 countries. See K. ALEXANDER, ET. AL., GLOBAL GOVERNANCE OF FINANCIAL SYSTEMS: THE INTERNATIONAL REGULATION OF SYSTEMIC RISK 68 (2006) (analyzing "the key issues of financial regulation with respect to the problem of systemic risk in financial systems and the need to devise global governance structures that can efficiently regulate financial markets while adhering to principles of accountability and efficiency.").

${ }^{41}$ For a comprehensive study of the evolution of international standard setting from one of government into one of "global governance," see Richard K. Gordon, On the Use and Abuse of Standards for Law: Global Governance and Offshore Financial Centers, 88 N.C. L. REV. 501 (2010); ALEXANDER, supra note 40, at 12. 
implement best practices or standards on a global basis" which "over time, [become] generally accepted regulatory standards." 42

As international law scholars have recognized, in this new regulatory environment, state sovereignty is "disaggregated; states act in the international system, not just through their executives, but through their various domestic governmental institutions, including ministries, courts, legislatures, and regulatory agencies."43 The FATF enforces compliance with its Recommendations through its own voluntary mutual evaluation process and through a series of sanctions, which it coordinates through its own membership and through other international organizations. Through the mutual evaluation process, each member of the FATF submits to periodic on-site evaluations by teams of experts drawn exclusively from other members, who prepare a report on the member's compliance with the Recommendations. ${ }^{44}$ In addition to ensuring compliance of its member jurisdictions, the FATF studies all observing and non-member jurisdictions as well. ${ }^{45}$ The FATF periodically publishes a list of "Non-Cooperative" jurisdictions and advises that FATF member jurisdictions take various counter-measures against the noncompliant jurisdictions, such as advising its domestic financial institutions to apply

\footnotetext{
${ }^{42}$ Richard K. Gordon, On the Use and Abuse of Standards for Law: Global Governance and Offshore Financial Centers, 88 N.C. L. REV. 501, 501-06 (2010).

${ }^{43} I d$.

${ }^{44}$ See Financial Action Task Force, http://www.fatfgafi.org/pages/0,3417,en_32250379_32236836_1_1_1_1_1,00.html..

${ }^{45}$ The FATF's decision to apply its standards to non-member jurisdictions has led some to criticize the legitimacy and accountability of its standard-setting process. See, e.g., Richard K. Gordon, On the Use and Abuse of Standards for Law: Global Governance and Offshore Financial Centers, 88 N.C. L. REv. 501 (2010); ALEXANDER, supra note 40, at 72.
} 
heightened scrutiny and due diligence to any financial transaction originating from a noncooperative jurisdiction. $^{46}$

Other international institutions enforce the FATF Recommendations. Most notably, in 2001, the World Bank and IMF first adopted the FATF's Recommendations as part of their financial sector assessment and adjustment programs and now condition eligibility for loans on compliance with the FATF's Recommendations. ${ }^{47}$ In addition, various multinational treaties now make reference to the FATF's Recommendations to clarify the meaning of treaty provisions. For example, the United Nations Convention against Transnational and Organized Crime (2000) (the Palermo Convention), which is widely regarded as "the most significant multilateral treaty addressing organized and financial crime," ${ }^{48}$ provided that signatories must implement AML measures according to the guidelines of the relevant multinational organizations. The treaty's imperative notes make clear that these guidelines include the FATF's Recommendations, and the subsequent implementation programs cross-reference the FATF Recommendations. ${ }^{49}$ As

\footnotetext{
${ }^{46}$ See Financial Action Task Force, High-Risk and Non-cooperative Jurisdictions, http://www.fatfgafi.org/pages/0,3417,en_32250379_32236992_1_1_1_1_1,00.html; see also ALEXANDER, supra note 40, at $68-72$.

${ }^{47}$ See, e.g., Richard K Gordon, On the Use and Abuse of Standards for Law: Global Governance and Offshore Financial Centers, 88 N.C. L. REV. 501 (2010); ALEXANDER, supra note 40, at 72; LOREN YAGER, ET AL., Gov. ACCOUNTABILITY OfFICE, COMBATING Illicit FinANCING: TREASURY's OFFICE OF TERRORISM AND FinANCIAL INTELligENCE COULD MANAGE MoRe EFFeCTIVEly to ACHIEVE ITS Mission (2009), available athttp://www.gao.gov/new.items/d09794.pdf; Financial Action Task Force, FATF Calls On All Countries to Join Combating Against Terrorist Financing (Sep. 10, 2002), http://www.oecd.org/dataoecd/45/36/33694265.pdf; Factsheet-The IMF and the Fight Against Money Laundering and the Financing of Terrorism, http://www.imf.org/external/np/exr/facts/aml.htm. According to the Treasury Department's 2007 National Money Laundering Strategy, "[b]y the end of 2005, the IMF and World Bank had conducted more than 50 assessments of member countries' compliance with the standards of the FATF and had provided technical assistance on related projects in more than 125 countries." U.S. TREASURY DEP'T, U.S. MONEY LAUNDERING THREAT ASSESSMENT, NATIONAL MONEY LAUNDERING STRATEGY 12 (2007), available at http://www.ustreas.gov/press/releases/docs/nmls.pdf.

${ }^{48}$ ALEXANDER, supra note 40, at 151.

${ }^{49} I d$.
} 
one international law scholar noted, the FATF's Recommendations have become "international law through the back door.",50

\section{B. The FATF's Gatekeeper Initiative}

One decade after FATF's formation, the G-8 heads of state adopted the Moscow Communiqué in 1999. It established the FATF's “Gatekeeper Initiative" to "consider requiring or enhancing suspicious transaction reporting by 'gatekeepers' to the international financial system, including company formation agents, accountants, auditors, and lawyers, as well as making the intentional failure to file the reports a punishable offense." $" 51$ The FATF issued a Consultation Paper in 2002, stating its "increasing concern" that money laundering schemes involved the use of gatekeeping professionals including lawyers, accountants, and financial advisers, as financial intermediaries or to provide expert advice. ${ }^{52}$ In 2003, the FATF issued a revised set of 40+9 Recommendations (herein after referred to collectively as the "FATF Recommendations") which expanded those subject to AML customer due diligence, record keeping, and reporting requirements to include lawyers when they "prepare for or carry out transactions for their clients" concerning the following five activities: (1) buying and selling of real estate; (2) managing of client money, securities or other assets; (3) management of bank, savings or securities accounts; (4) organization of contributions for the creation, operation or management of companies; and (5) creation, operation or

\footnotetext{
${ }^{50} I d$. at 152.

${ }^{51}$ Shepherd, supra note 10, at 611, n. 32 (quoting the Moscow Communiqué).

${ }^{52}$ See Am. Bar Assoc., Task ForCe ON GateKeEPER Regulations AND the Legal Profession, COMMENTS ON GATEKEEPER PROVISIONS OF FATF CONSULTATION PAPER (April 2003), available at http://www.abanet.org/crimjust/taskforce/actions/gatekeeper.pdf.
} 
management of legal persons or arrangements, and buying and selling of business entities. $^{, 53}$

After considerable debate, ${ }^{54}$ the FATF issued its Lawyer Guidance, in which it adopted a risk-based approach to customer due diligence. ${ }^{55}$ The Lawyer Guidance provides risk criteria, grouped under three main categories: geographic risk, client risk, and risk associated with the particular type of transaction. The Lawyer Guidance then instructs that attorneys should engage in heightened due diligence where risk factors are present, but are permitted to engage in lesser due diligence where risk factors are absent. The Lawyer Guidance explicitly did not address the FATF Recommendations regarding suspicious transaction reporting by lawyers, explaining that the Lawyer Guidance applies only to implementing the FATF Recommendations concerning risk assessment, not those addressing response mechanisms once those suspicions are formed. ${ }^{56}$

\section{Anti-Money Laundering Gatekeeper Regulation of Attorneys Abroad}

Many jurisdictions around the world have enacted legislation pursuant to the FATF's amended Recommendations, which apply the AML regime to attorneys when conducting certain commercial transactions on behalf of clients. ${ }^{57}$ For example, in

\footnotetext{
${ }^{53}$ Recommendation 12 of the revised Recommendations lists the five situations where the customer due diligence, record keeping, and suspicious transaction reporting requirements will apply to attorneys. FATF, The 40 Recommendations, http://www.fatfgafi.org/document/28/0,3343,en_32250379_32236920_33658140_1_1_1_1,00.html.

${ }^{54}$ For a detailed description of the debate, see Shepherd, supra note 10.

${ }^{55}$ See Financial Action Task Force, RBA Guidance for Legal Professionals, Oct. 23, 2008, available at http://www.fatf-gafi.org/dataoecd/5/58/41584211.pdf.

${ }^{56}$ Id. at para. 120.

${ }^{57}$ For a current list of jurisdictions that have enacted legislation applying the AML obligations to attorneys, see IBA Anti-Money Laundering Forum, http://www.anti-moneylaundering.org/globalchart.aspx. In other jurisdictions, organized bar associations have successfully fought the application of the AML requirements to its member attorneys. For example, in response to Canadian legislation known as the Proceeds of Crime (Money Laundering) and Terrorist Financing Act, which applied AML reporting requirements to lawyers,
} 
response to the FATF Recommendations, the European Commission issued a directive requiring that all Member States enact legislation extending AML obligations to certain service professionals, including transactional attorneys. ${ }^{58}$ Pursuant to this directive, the United Kingdom ("UK") passed the Proceeds of Crime Act of 2002 and the Money Laundering Regulations of 2003, which require transactional attorneys to engage in client due diligence and report to the Director of the National Criminal Intelligence Service circumstances that would give reasonable grounds for suspecting money laundering by their clients. ${ }^{59}$ Transactional attorneys in the UK have been imprisoned for failure to report suspicious circumstances based on the Proceeds of Crime Act's negligence, or "willful blindness," standard.

Attorneys have criticized this legislation because of its requirement to file SARs. The Proceeds of Crime Act required lawyers to report suspicious activities to a government entity. Attorneys believe that "they were being put to a great deal of wasted time and expense for no benefit to anyone."60 Paradoxically, however, they worried that they might be found complicit in money laundering scheme, which resulted in voluminous filings of SARs. ${ }^{61}$ Although the UK has clarified instances in which

the Federation and the Law Society of British Columbia, supported by the Canadian Bar Association, challenged the constitutionality of the law. The bar associations were granted an interim injunction by the Supreme Court of British Columbia, pending a full hearing on the merits of the case. The Attorney General of Canada agreed to suspend the application of the law to attorneys, thus adjourning the case.

${ }^{58}$ See EU's Third Money Laundering Directive (2005/60/EC). For a current list of Member States that have enacted legislation incorporating this Directive, see IBA Anti-Money Laundering Forum-European Chart, http://www.anti-moneylaundering.org/EuropeanChart.aspx.

${ }^{59}$ UK's Proceeds of Crime Act of 2002 (sections 330-334) and the Money Laundering Regulations of 2003

${ }^{60}$ Colin Tyre, Anti-Money Laundering Legislation: Implementation of the FATF Forty Recommendations in the European Union, 2010 Journal of the Professional Lawyer 69, 78 (2010).

${ }^{61} I d$. at 77-79. For example, "features of the regime has been to encourage solicitors to make a huge number of defensive reports and consent applications, in order to ensure that they do not unwittingly 
solicitors are required to file SARs, it has relied on legislation to prosecute solicitors who fail to file SARs in accordance with the law.

For example, Phillip Griffiths, a Shrewsbury solicitor, was acquitted of charges that he knowingly aided his client's money laundering, but he was convicted and sentenced to incarceration for six months based on his failure to report suspicious circumstances. $^{62}$ Griffiths's conviction was based on his role as the conveyancer solicitor for a property that was significantly undervalued. The client reportedly told Griffiths that he was buying the property from friends who were in financial distress and were willing to sell the property for the balance on their mortgage. In fact, the client was purchasing the property pursuant to a money laundering agreement with a drug racketeering seller. ${ }^{63}$ The jury and the appellate court accepted that Griffiths, who performed the transaction for his normal convenyancing fee of 399 pounds, did not know of the money laundering purpose behind the transaction. ${ }^{64}$ Finding that Griffiths "closed [his] eyes to what would otherwise have been the clearest of evidence," the appellate court explained that "society demands a high degree of professionalism from solicitors. They are one of the door keepers of financial probity in connection with this legislation and it is one of the obligations to which each one will be required to measure up to the hilt."65

commit a criminal offense by facilitating money laundering." Id. at 78 . In the fiscal year that ended on September 30, 2009 solicitors filed 228,834 SARs. See id. at 78 n.27.

${ }^{62}$ Regina v. Philip Griffiths, [2006] EWCA Crim 2155.

${ }^{63} I d$.

${ }^{64} I d$.

${ }^{65} I d$. Attorneys may also be convicted under the substantive provisions of the Proceeds of Crime Act under the willful blindness standard. For example, Brian Dougan, a solicitor in Northern Ireland, was jailed for three months for allowing 66,500 pounds in tainted money to pass through his lawyer trust account. The judge accepted that Dougan was a "naïve victim of a sophisticated criminal," but said that solicitors must "take the greatest care" to not allow their services to be used for money laundering 
While the UK's Proceeds of Crime Act appears to exempt privileged communications from the reporting requirement, the Act provides that the protection of the privilege does not apply where "the information or other matter is communicated or given with the intention of furthering a criminal purpose." 66 Visiting lawyers practicing in Europe, such as American lawyers in European offices of United States based law firms, are also subject to these laws and could be jailed for violations. ${ }^{67}$

\section{Anti-Money Laundering Gatekeeper Regulation of Attorneys in the United States}

\section{Current AML Regulation of Attorneys and the FATF Mutual Evaluation}

Currently, lawyers in the United States are not obligated to comply with the AML gatekeeper regulations concerning customer due diligence, record keeping, or suspicious activity reporting. They are governed, however, by other AML laws. Attorneys who participate in a client's scheme to launder money, or who assist the laundering of illicit funds for their clients may be held criminally liable under the money laundering statutes. ${ }^{68}$ A lawyer may have her legal fees subject to forfeiture under the money laundering laws, if that fee was paid from illicit client funds, ${ }^{69}$ and lawyers who receive

purposes. See Mike Sturgess, Two Solicitors Jailed Under Money Laundering Provisions (Oct. 26, 2006), available at

http://www.swat.co.uk/NewsViews/TechnicalNews/tabid/149/articleType/ArticleView/articleId/2523/Defa ult.aspx.

${ }^{66}$ UK’s Proceeds of Crime Act $\S \S 330$ (10-11). See also Bowman v. Fels [2005] EWCA Civ. 226.

${ }^{67}$ For a discussion of this risk, see The International Bar Association's Anti-Money Laundering Forum, http://www.anti-moneylaundering.org/europe/united_kingdom.aspx.

\footnotetext{
${ }^{68}$ See, e.g., United States v. Flores, 454 F.3d 149 (2006) (lawyer convicted of money laundering based on "willful blindness" theory where attorney formed numerous shell companies for client, named himself president of those companies, facilitated numerous wire transfers on behalf of the companies and did not inquire regarding source of client funds); United States v. Landerman, 167 F.3d 895 (5th Cir. 1999) (attorney convicted of money laundering where he established shell companies to launder illicit funds and laundered tainted client money through his attorney trust account).

${ }^{69}$ Caplin \& Drysdale v. United States, 491 U.S. 617 (1989) (holding that a defendant does not have a constitutional right to use forfeitable assets to pay for or to secure an attorney). Note, however, that criminal defense attorneys may not be held criminally liable for money laundering when they receive
} 
currency in the amount of $\$ 10,000$ or more are required to file a currency transaction report. $^{70}$

Additionally, lawyers in the Untied States are obligated by state ethics rules that govern their conduct when confronted with a client's wrongdoing. A lawyer may not assist a client in conduct that she knows is criminal or fraudulent. ${ }^{71}$ A lawyer who believes her services are being used in the furtherance of a crime or fraud is obligated to withdraw from the representation, ${ }^{72}$ and a lawyer may disclose an individual client's wrongdoing if her services were used in perpetuating the crime or fraud and she believes the disclosure is necessary to prevent, mitigate, or rectify, financial harm to another. ${ }^{73}$ The FATF subjected the United States to a mutual evaluation in 2006. The FATF rated the United States as "noncompliant" with the FATF Recommendations requiring the implementation of AML Gatekeeper regulations, because designated financial intermediaries, including lawyers, are not subject to customer identification and record

client's proceeds of crime as legal defense fees. See United States v. Velez, 586 F.3d 875 (11th Cir. 2009) (finding the defendant exempt from criminal prosecution under s.1957(a) because the plain language of 1957(f)(1) excludes from the statute "any transaction necessary to preserve a person's right to representation as guaranteed by the Sixth Amendment to the Constitution," and explaining that "the exemption for attorneys' fees as a crucial distinction between the criminal charges at issue under $\$ 1957$ and the forfeiture provision" from Caplin \& Drysdale.).

${ }^{70}$ See, e.g., United States v. Sindel, 53 F.3d 874, 877 (8th Cir. 1995) (holding application of federal regulation requiring currency transaction report to attorney who receive $\$ 10,000$ or more in cash did not violate Sixth Amendment, client's name not protected from disclosure on form by attorney-client privilege; but, expressing, in dictum, concern regarding the Sixth Amendment implications of requiring attorney to indicate whether the transaction is suspicious).

${ }^{71}$ See Model Rules of Professional Responsibility 1.2 (d).

${ }^{72}$ See Model Rule of Professional Responsibility 1.16(a). In some instances, where the attorney's services have been used in furtherance of the client's fraud or crime, and a third party is relying upon a statement by the attorney, the attorney may be required to withdraw the statement. See Model Rules of Professional Responsibility 4.1(b).

${ }^{73}$ See Model Rule of Professional Responsibility 1.6 (b)(2) and (3). Where the lawyer's client is an entity, the lawyer is required to report certain client wrongdoing to the highest authority in the organization, and if action is not taken, the attorney may disclose the wrongdoing to authorities outside of the organization. See Model Rule of Professional Responsibility 1.13. 
keeping requirements or to suspicious transaction reporting. ${ }^{74}$ The FATF further found the United States non-compliant, because no regulatory oversight exists to ensure the professionals' compliance with the requirements. ${ }^{75}$ The FATF allowed the United States two years to implement steps necessary to comply with the FATF Recommendations or risk sanctions by the FATF, which could include expulsion from the FATF. ${ }^{76}$

\section{Pending Federal Initiatives}

Congress and Treasury have various measures pending that may apply AML gatekeeper regulations to attorneys. Pending legislation and rule-making indicate that the United States may apply due diligence, record keeping, and suspicious transaction reporting requirements to attorneys when they are acting within three contexts: 1) real estate closings and settlements; 2) company formation; and 3) handling client funds through lawyer trust accounts.

In the previous Congress, law makers proposed legislation that would require the Secretary of the Treasury to publish a proposed and final rule to require persons, including lawyers, who are involved in forming a corporation, limited liability company, partnership, trust, or other legal entity, to engage in customer due diligence, including the gathering of information regarding beneficial ownership of the entity, as well as keep certain records, and engage in suspicious transaction reporting. ${ }^{77}$ This proposal is due, in part, to the FATF's rating the United States as non-compliant.

\footnotetext{
${ }^{74}$ See Financial Action Task Force, Summary of the Third Mutual Evaluation Report on Anti-Money Laundering and Combating the Financing of Terrorism: United States of America (2006), available at http://www.fatf-gafi.org/dataoecd/44/12/37101706.pdf [hereinafter "U.S. Evaluation"].

${ }^{75}$ See id.

${ }^{76}$ See id.
} 
Lawyers conducting real estate transactions may also be obligated by the due diligence, record keeping, and suspicious activity reporting requirements of the Bank Secrecy Act. The Patriot Act amendments to the Bank Secrecy Act broadened the term "financial institution," the term defining those obligated by the Bank Secrecy Act's regulations, beyond traditional financial institutions, such as depository institutions, credit unions, securities brokers, and futures and commission merchants, to include nontraditional financial intermediaries. This new designation included "dealers in precious metals, stones or jewels, pawnbrokers, loan or finance companies, private bankers, insurance companies, travel agencies, telegraph companies, sellers of vehicles, and ... persons engaged in real estate closings and settlements." ${ }^{, 79}$ In April of 2003, FinCEN issued an Advance Notice of Proposed Rulemaking requesting comments on such a rule ${ }^{80}$ but has not progressed further in the official rule-making process.

On April 29, 2002, and again on November 6, 2002, FinCEN temporarily exempted "persons involved in real estate closings and settlements," from the AML requirements, pending FinCEN's study of the affected industries, ${ }^{81}$ and on April 10, 2003, FinCEN

\footnotetext{
${ }^{77}$ See S.569 Incorporation Transparency and Law Enforcement Assistance Act, 1 S.569 (2009) and S. 2956 (2008). For a thorough history and cost-benefit analysis of this legislation, see J.W. Verret, Terrorism Finance, Business Associations, and the Incorporation Transparency Act, 70 LA. L. REV. 857 (2010); see also Stop Tax Haven Abuse Act, S. 506 and H.R. 1265 (2009), S. 681, $110^{\text {th }}$ Cong. (2007). While tax evasion is not a predicate crime for money-laundering, recovering federal revenue through the suppression of tax evasion is another justification cited for bills to increase transparency in company formation.

${ }^{79}$ Patriot Act, 31 U.S.C. Section 5312(a)(2)(U) (2003) (emphasis added).

${ }^{80}$ The Secretary of the Treasury has the statutory authority to designate any business as a "financial institution" for purposes of extending anti-money laundering requirements, including suspicious activity reporting requirements to that entity. See 31 U.S.C. § 5312(a)(2) (a "financial institution" includes "any business or agency which engages in any activity which the Secretary of the Treasury determines, by regulation, to be an activity which is similar to, related to, or a substitute for any activity in which any business described in this paragraph is authorized to engage; or (Z) any other business designated by the Secretary whose cash transactions have a high degree of usefulness in criminal, tax, or regulatory matters.").
} 
issued an Advance Notice of Proposed Rulemaking and request for comments on including persons involved in real estate closings and settlements, including settlement attorneys, as persons subject to AML regulation. ${ }^{82}$ This rule-making process lay dormant for several years, but it has resurfaced in the wake of the financial crisis of 2008, which has focused FinCEN and Congress's attention on real estate mortgage fraud.

The United States Senate Committee on Homeland Security and Government Affairs Permanent Subcommittee on Investigations held Hearings in February of 2010 wherein James H. Freis, Jr., Director FinCEN, testified that the "next step toward applying [AML] requirements to the non- bank mortgage industry" will be to consider additional participants in the real estate and finance sectors, including real estate attorneys. ${ }^{83}$ At the conclusion of those Hearings, the Committee published a 330-page bipartisan report, in which the Committee discussed a case involving lawyer facilitation of transactions used to launder elicit funds and called upon Treasury to end the exemptions it granted to the Patriot Act's AML requirements. ${ }^{84}$ The Report also called upon Treasury to instruct banks to subject attorney trust accounts to greater scrutiny and

${ }^{81}$ See Financial Crimes Enforcement Network, Anti-Money Laundering Programs for Financial Institutions, 67 Fed. Reg. 67547 (Nov. 2, 2002).

${ }^{82}$ Financial Crimes Enforcement Network, Anti-Money Laundering Program for Persons Involved in Real Estate Closings and Settlements, 68 Fed. Reg. 17569 (Apr. 10, 2003).

${ }^{83}$ Acknowledging that "a common theme among comments received" during the rule-making comment period was "that imposing AML requirements on real estate settlement lawyers would seriously undermine the attorney-client privilege and the right to client confidentiality," Mr. Freis cited FinCEN's work with the American Bar Association to develop voluntary guidance regarding risk-identification through client due diligence. However, he did not discuss FinCEN's position on lawyer obligations when risk is identified, such as whether lawyers would be obligated to report suspicious transactions. Keeping Foreign Corruption Out of the United States: Four Case Histories, Hearing Before the S. Comm. on Homeland Security and Government Affairs, (2010) (statement of James H. Fries, Jr., Director, Financial Crimes Enforcement Network, United States Dep't of the Treasury), available at http://levin.senate.gov/newsroom/release.cfm?id=322088.

${ }^{84}$ See Press Release, Senator Carl Levin, Investigations Subcommittee Holds Hearing on Keeping Foreign Corruption Out of the United States: Four Case Histories (Feb. 4, 2010), available at http://levin.senate.gov/newsroom/release.cfm?id=322088. 
regulation. $^{85}$

The Federal Government continues to consider legislation in order to ensure American compliance with the FATF. Specifically, Congressional concern centers on its membership in the FATF. The political landscape, which involves fighting terrorism and money laundering in the international community, makes it unlikely that the United States "will want to be expelled from" the FATF. ${ }^{86}$ FATF membership, however, contains obligations that will require the United States either to "cure the problems in its FATF mutual evaluation, which means that it will need to be viewed as complain with FATF," or potentially to be expelled from the organization. ${ }^{87}$

At least one commentator argues that lawyers in the United States should be cognizant of possible changes to lawyer regulation based on FATF requirements. She suggests that "lawyers should expect to see changes in U[nited] S[tates] legal practice, if not lawyer regulation, as a result of the FATF's non-binding, soft-law policies." 88 She maintains that developments in international standards and other types of soft-law can have profound effects on lawyers in both practice and regulation. ${ }^{89}$

Congress, in fact, already has usurped some self-regulatory authority from the legal profession, which had been largely self-regulated. For example, Congress's adoption of the Sarbanes-Oxley Act of 2002 "in the aftermath of Enron and other

\footnotetext{
${ }^{85}$ See id.

${ }^{86}$ Larel S. Terry, An Introduction to the Financial Action Task Force and Its 2008 Lawyer Guidance, 2010 J. PROF'L. LAWYER 3, 48 (2010).

${ }^{87} I d$.

${ }^{88} I d$.

${ }^{89} I d$.
} 
corporate scandals has meant a recalibration of the fundamental understanding about the appropriate distance between government and regulation of lawyer activities." 90 Sarbanes-Oxley was the first federal statute "to regulate lawyers directly and broadly."91 Congress enacted a second statute two years later "when Congress confirmed and extended the power of the [IRS] to regulate extensively the practice of tax lawyers."92 Professor Simon warns that "[i]t seems likely that the trend toward displacement of the states and the bar as the primary regulators of the profession will continue." 93 His assessment is only bolstered by the limited jurisdictional scope of the states as it relates to the growing national and international practice of law.

Lawyers' concern with federal involvement is warranted. As Professor Patton warns, "[w]hen national governments get into the habit of having a new resource of obtaining information on criminal activity, they are not going to give it up again very lightly."94 Although Federal proposals did not pass in the 111th Congress, similar legislation may be introduced in the 112th Congress. In light of the continued governmental focus on fighting terrorism and the money used to fund its activities, it is

\footnotetext{
${ }^{90}$ Paul D. Paton, Cooperation, Co-option or Coercion? The FATF Lawyer Guidance and Regulation of the Legal Profession, 2010 J. PROF'L. LAWYER 165, 166 (2010).

${ }^{91}$ William H. Simon, Introduction: The Post-Enron Identity Crisis of the Business Lawyer, 74 FORDHAM L. REV. 947, 950 (2005).

${ }^{92} I d$. As Professor Simon notes, "prior to these statutes, regulation of the legal profession was considered a matter for the states and in important respects a matter of self-regulation." Id. He notes, however, that "the profession has never had formal power to regulate itself." Id. Instead, state courts have the formal power to regulate the bar, but they "have tended to acquiesce in the proposals of the bar associations, and every jurisdiction has some version of the $[\mathrm{ABA}]$ model norms." Id. Additionally, although "federal agencies have preempted some state rules to regulate the lawyers who practice before them," they have done so on a generally narrow basis. Id. Professor Smith notes that Sarbanes-Oxley was "a much more dramatic step" because the federal government issued its own judgment that, at least to some extent, "the bar's self-regulatory efforts have been inadequate." $I d$.

${ }^{93} I d$.

${ }^{94}$ See Paton, supra note 90 at 189 . This situation would likely arise if lawyers are required to file SARs to a federal authority, as is the case in the UK. See supra notes 60-61 and accompanying text.
} 
likely that the federal government will take the steps necessary to avoid expulsion from the FATF. Lawyers, then, should focus on the ABA's proposals to comply with the FATF's regulations because a failure for the ABA to propose meaningful lawyer guidelines likely will result in unwanted federal regulation.

\section{American Bar Association Resistance to Federal AML Gatekeeper Regulation and Creation of Voluntary Good Practices Guidance}

The ABA has fought the FATF's and the federal government's initiatives that would impose mandatory due diligence, record keeping, or suspicious activity reporting on attorneys. ${ }^{95}$ In February of 2002, the ABA established its own Task Force on Gatekeeper Regulation and the Profession (“ABA Task Force”). Since that time, the ABA Task Force has worked to counter the imposition of the AML gatekeeping regulations on attorneys by working directly with the FATF ${ }^{96}$ and Treasury on ABA voluntary guidelines, preparing reports and recommendations to the ABA House of Delegates, ${ }^{97}$ and testifying before Congress on behalf of the ABA in opposition to legislation that would impose the AML gatekeeping requirements. ${ }^{98}$ In February of 2003, the ABA House of Delegates

\footnotetext{
95 See Am. BAR Assoc., TASK ForCE ON GATEKEEPER REgUlAtion AND THE PROFESSION, REPORT ACCOMPANYING EXEC SUMM. RES. 300 (2008), available at http://www.abanet.org/leadership/2008/annual/recommendations/ThreeHundred.doc.

96 The ABA Task Force participated in the FATF Working Group on Gatekeepers and provided formal comments on the FATF's 2002 Consultation Paper. See AM. BAR Assoc., TASK ForCE ON GATEKEEPER REgulations AND THE LEgAl PROFESSION, COMMENTS ON GATEKEEPER PROVISIONS OF FATF CONSULTATION PAPER (April 9, 2003), available at http://www.abanet.org/crimjust/taskforce/actions/gatekeeper.pdf.

97 AM. BAR ASSOC., TASK FORCE ON GATEKEEPER REGULATION AND THE PROFESSION, REPORT ACCOMPANYING EXEC SUMM. RES. 300 (2008), available at http://www.abanet.org/leadership/2008/annual/recommendations/ThreeHundred.doc.

${ }^{98}$ See Incorporation Transparency and Law Enforcement Assistance Act: Hearing on S. 569 Before the S. Comm. on Homeland Security and Governmental Affairs (2009) (statement of Kevin L. Shepherd, Member, Task Force on Gatekeeper Regulation and the Profession, on behalf of the American Bar Association), available at http://hsgac.senate.gov/public/index.cfm?FuseAction=Hearings.Hearing\&Hearing_ID=88d1a5fb-73124e9e-92b2-8558ccd44f22.
} 
adopted Resolution 104, expressing its policy that the ABA “[o]pposes any law or regulation that, while taking action to combat money laundering or terrorist financing, would compel lawyers to disclose confidential information to government officials or otherwise compromise the lawyer-client relationship or the independence of the bar." 99 In 2008, the ABA House of Delegates adopted Resolution 300, expressing its policy that the ABA “[o]ppos[es] federal legislation that would impose obligations on company formation agents, including lawyers, to undertake extensive due diligence and determine 'beneficial owners' when assisting in the formation of non-publicly traded business entities and trusts."

In an effort to "negat[e] the need for federal regulation of the legal profession," 101 the ABA Task force on Gatekeeper Regulation and the Profession, in collaboration with among others, the American College of Commercial Finance Lawyers and the ABA Criminal Justice Section, recently established "Voluntary Good Practices Guidance for Lawyers to Detect and Combat Money Laundering and Terrorist Financing" ("Good Practices"), which was adopted by the ABA in August of 2010.

\footnotetext{
${ }^{99}$ See ABA Resolution 104, adopted at the ABA Midyear Meeting in February of 2003, attached to AM. BAR ASSOC., TASK FORCE ON GATEKEEPER REgUlATION AND THE PROFESSION, REPORT ACCOMPANYING EXEC SUMM. RES. 300 (2008), available at http://www.abanet.org/leadership/2008/annual/recommendations/ThreeHundred.doc.

${ }^{100}$ See AM. Bar Assoc., TASK Force ON GATEKeEPER Regulation AND the Profession, RePORT ACCOMPANYING EXEC SUMM. RES. 300 (2008), available at http://www.abanet.org/leadership/2008/annual/recommendations/ThreeHundred.doc.

${ }^{101}$ VOLUNTARY GOOD PRACTICES GUIDANCE FOR LAWYERS TO DETECT AND COMBAT MONEY LAUNDERING AND TERRORIST FINANCING 3 (stating that the "federal government is under pressure from FATF and others (including development agencies, the Organization for Economic Co-Operation and Development, the International Monetary Fund, The World Bank, and the United Nations) to adopt legislation implementing some or all of the provisions of the Lawyer Guidance. An overarching purpose of this paper is to encourage lawyers to develop and implement voluntary, but effective, risk-basked approaches consistent with the Lawyer Guidance, thereby negating the need for federal regulation of the legal profession.") [hereinafter "Good Practices"].
} 
The Good Practices is a comprehensive manual intended to educate lawyers on client risk-assessment, and it incorporates the FATF's risk-based approach to customer due diligence. The Good Practices, however, does not include an ethical obligation to report the lawyer's suspicions. Rather, it instructs that if a "client presents an unacceptable risk," the lawyer should decline or withdraw from the representation. ${ }^{102}$ Specifically, when involved in the purchase and sale of real estate, the Good Practices advises lawyers to engage in heightened due diligence if the client requests the "[t]ransfer of real estate between parties in a time period that is unusually short for similar transactions with no apparent legal, tax, business, economic or other legitimate reason,"103 or if the client or other party provides inadequate consideration for property, with no apparent legitimate explanation. $^{104}$

With regard to obtaining beneficial ownership information, the Good Practices mirrors the FATF Lawyer Guidance, but falls short of the requirements contained in legislation proposed in the previous Congress. It explains that while the lawyer should collect enough basic client information "such that the lawyer is reasonably satisfied that the lawyer knows who the beneficial owner is," and should perform an "OFAC scan,",105 the lawyer need not engage in any further due diligence to collect beneficial owner information, unless certain risk factors are present. These include the client's

\footnotetext{
${ }^{102}$ Id. at 38 .

${ }^{103}$ Id. at para. 3.4.

${ }^{104}$ Id. at para. 3.7.

105 The Office of Foreign Assets Control (“OFAC") of the U.S. Department of the Treasury "publishes a list of individuals and companies owned or controlled by, or acting for or on behalf of, targeted countries. It also lists individuals, groups, and entities, such as terrorists and narcotics traffickers designated under programs that are not country-specific. Collectively, such individuals and companies are called 'Specially Designated Nationals' or 'SDNs.' Their assets are blocked and U.S. persons are generally prohibited from dealing with them." See OFAC, http://www.ustreas.gov/offices/enforcement/ofac/faq/answer.shtml\#17.
} 
"unexplained or seemingly unnecessary use of legal persons or legal arrangements,",106 such as bearer shares, ${ }^{, 107}$ shell companies, ${ }^{108}$ or legal trusts. ${ }^{109}$ For lawyer trust accounts, the Good Practices endorses the "classic touch the money" test, advising that any time the lawyer handles client money, the lawyer should "be aware of not only the source of funds transferred to a trust but the use of the funds by the trustee." 110

The ABA has based its opposition to federal gatekeeper AML regulation, and in particular, any regulations that would require attorneys engaged in entity formation to engage in heightened due diligence to obtain beneficial owner information and those that would require transactional lawyers to engage in suspicious transaction reporting, on three primary grounds: 1) concerns that the regulations will have a negative impact on aspects of the lawyer-client relationship, including confidentiality, the attorney-client privilege, lawyer independence, and the attorney's duty of loyalty; ${ }^{111}$ 2) Constitutional arguments based on the Sixth and Tenth Amendments; ${ }^{112}$ and 3) the lack of empirical data showing that, as a threshold matter, lawyers are used to facilitate transactions for

\footnotetext{
${ }^{106}$ Good Practices at para. 2.11.

${ }^{107}$ Id. at para. 2.3. The Good Practices stresses that "there may be legitimate reasons to keep confidential the business ownership of an entity from the public because of business competitive reasons," and that the concealment of beneficial ownership is only a red flag if such concealment has no apparent legitimate purpose. Id. at para. 3.2 and accompanying Practice Pointer.

${ }^{108} I d$. at para. 3.11.

${ }^{109} I d$. at para $3.12 ; 3.14$.

${ }^{110}$ Id. at para. 3.1 and accompanying Practice Pointer.

${ }^{111}$ See AM. BAR AsSOC., TASK ForCe ON GATEKEEPER Regulation AND THE PROFESSION, REPORT ACCOMPANYING EXEC SUMM. RES. 300 (2008), available at http://www.abanet.org/leadership/2008/annual/recommendations/ThreeHundred.doc.

${ }_{112}$ The ABA argues that the reporting requirements would violate the client's Sixth Amendment right to counsel and that the imposition of these federal regulations on the legal profession could run afoul of the Tenth Amendment. See id.
} 
money laundering clients. ${ }^{113}$ This Article seeks to address the third question-whether

lawyers are used to facilitate transactions to launder money such that they are in a

position to serve as gatekeepers to the financial system.

\section{Second Circuit Empirical Study}

This Section describes the empirical study of money laundering cases filed in the

Second Circuit in 2009 on which the authors relied to create their data set. It then

extrapolates this data to offer conclusions on the extent to which clients relied on their

attorney's services to launder money.

\section{A. Methodology}

The authors conducted a quantitative descriptive ${ }^{115}$ study to explore the frequency

of lawyer involvement in commercial transactions employed to launder illicit funds. The

study examined archival data from federal criminal money laundering cases acted upon in

\footnotetext{
${ }^{113} I d$. at 7. (Asserting that "[i]t is evident that insufficient information has been obtained and analysis conducted to determine the relative costs and benefits of any STR requirement for the legal profession," and that "there is no indication that the U.S. government has undertaken any meaningful examination, consideration, or cost-benefit analysis of these issues. ...At a minimum, this should be done before the U.S. government formulates any policy on the Gatekeeper Initiative."). See also Neil Rose, Making the Case for Appropriate Anti-Money Laundering Rules for Lawyers, International Bar News, 37-39 (April 2009), available at http://www.anti-moneylaundering.org/AMLResources.aspx\#FeArticles (interview with Stephen Revell, Chair of the International Bar Association (IBA) Anti-Money Laundering Legislation Implementation Group, who explained that the IBA has strongly requested such data from the FATF, explaining that the FATF has not provided any data regarding whether lawyers are unwittingly involved in transactions that facilitate money laundering, which he claims is needed in order to justify the AML gatekeeping regulation of lawyers). The FATF asserted in its 2000-2001 Report on Money Laundering Typologies that "[l]awyers, notaries, accountants and other professionals offering financial advice have become the common elements to complex money laundering schemes," and that "[ $[$ this trend is mentioned by almost all FATF members." FIN. ACTION TASK FORCE ON MONEY LAUNDERING, REPORT ON MONEY LAUNDERING TYPOLOGIES 12 (Feb. 1, 2001), available at http://www.fatfgafi.org/dataoecd/29/36/34038090.pdf. However, this report was prepared based solely on anecdotal evidence self-reported by participating jurisdictions. See id. As Kevin L. Shepherd, Member of the ABA Gatekeeper Task Force stated, "The paucity of typologies describing situations in which lawyers have been used unwittingly in money laundering schemes is a particular pointed criticism," explaining that "FATF has not produced to the legal profession typologies in which lawyers have been unwitting accomplices in money laundering schemes." Shepherd, supra note 10, at 629.

${ }^{115}$ Descriptive research is used to summarize the relationship between two or more variables. See Bickman, L. \& Rog, D.J. (Eds.) HANDBOOK OF APPLIED Social RESEARCH METHOdS (Thousand Oaks: Sage 2009). As Bickman and Rog explain, "a descriptive approach is appropriate when the researcher is attempting to answer 'what is' or 'what was' questions" Id. at p. 16.
} 
the Second Circuit Court of Appeals within calendar year 2009. The sample of this study was drawn from federal money laundering cases in the Second Circuit because a disproportionately high number of money laundering convictions emanate from the Second Circuit. Of the 812 defendants sentenced in 2009 pursuant to the money laundering statutes, 123 of the defendants were sentenced in the Second Circuit. ${ }^{116}$

The data set consisted of money laundering cases with some court action taken in 2009, including initial filing of charges, plea, sentencing, and evidentiary hearings. In order to reduce the possibility that the study would be subject to selective deposit bias (not all possible data were recorded by the source), data was gathered from multiple sources. Searches were conducted in Westlaw and LexisNexis databases, which included court filings, pleadings, opinions, and court dockets databases, and the databases were combined. The electronic court records associated with each case were pulled from Westlaw, LexisNexis, and the Federal Court's PACER ${ }^{117}$ system and thoroughly read, analyzed, and coded by research assistants who are George Washington University Law School students or graduates. ${ }^{118}$ These research assistants underwent extensive initial

\footnotetext{
${ }^{116}$ United States Sentencing Commission, Statistical Information Packet, Fiscal Year 2009, Second Circuit, at tbl. 1, available at http://www.ussc.gov/JUDPACK/2009/2c09.pdf. It is important to note that this number represents the number of individual defendants sentenced in the Second Circuit. Many of those defendants were charged as co-defendants pursuant to a much smaller number of cases.

${ }^{117}$ As stated on its website, "Public Access to Court Electronic Records (PACER) is an electronic public access service that allows users to obtain case and docket information from federal appellate, district and bankruptcy courts, and the PACER Case Locator via the Internet. PACER is provided by the federal Judiciary in keeping with its commitment to providing public access to court information via a centralized service." PACER can be accessed through www.pacer.gov.

${ }^{118}$ In 2009, while the national plea rate for money laundering convictions was $93.5 \%$, in the Second Circuit, 121 of 123, or $98.4 \%$ of all money laundering convictions in the Second Circuit were obtained through plea. See United States Sentencing Commission, Statistical Information Packet, Fiscal Year 2009, Second Circuit, at Table 3, available at http://www.ussc.gov/JUDPACK/2009/2c09.pdf. Therefore, the document that yielded the most information relevant to the study was often the Indictment. Because one of the elements of money laundering is a transaction, the Government's statement of facts usually included the basic facts surrounding the transaction used to launder the funds.
} 
training conducted by the authors, as well as ongoing training pursuant to weekly spot checks by the authors. The assistants eliminated irrelevant and redundant cases from the database and grouped documents from related cases. In order to minimize potential skewing of results caused by cases with multiple defendants who were charged pursuant to the same underlying facts and transactions, co-defendants were grouped together under a single data point. Once multiple case numbers and defendants were grouped by underlying facts, we drew forty data points (henceforth referred to as "cases") from the remaining cases to include in the sample. ${ }^{119}$ To ensure accuracy, the authors spotchecked the assistants' work during the case elimination phase, and the authors thoroughly examined every case included in the final sample.

\footnotetext{
${ }^{119}$ United States v. Wright, 341 Fed. Appx. 709 (2d Cir. 2009); United States v. Wright, 2009 WL 6040567 (2d Cir. Dec. 14, 2009); United States v. Venkataram, 356 Fed. Appx. 541 (2d. Cir. 2009); Novak v. United States, 2009 WL 982429 (E.D.N.Y. Apr. 13, 2009); Mora v. United States, 2009 WL 36779 (E.D.N.Y. Jan. 6, 2009); Montserrat v. United States, 2009 WL 2230678 (E.D.N.Y. July 24, 2009); Gotti v. United States, 2009 WL 197132 (E.D.N.Y. Jan. 28, 2009); Bennett v. United States, 2009 WL 3614613 (S.D.N.Y. Nov. 3, 2009); United States v. Tyson, 338 Fed. Appx. 38 (2d Cir. 2009); United States v. Kontogiannis, 2009 WL 1701930 (E.D.N.Y. June 3, 2009); United States v. Salce, 2009 WL 3713690 (D. Conn. Oct. 30, 2009); United States v. Ramerez, 355 Fed. Appx. 467 (2d Cir. 2009); United States v. Follieri, 2009 U.S.Dist LEXIS 3783 (S.D.N.Y. January 21, 2009); United States v. One 2004 Land Rover Range Rover, 2009 WL 909669 (W.D.N.Y. Mar. 31, 2009); United States v. One 2003 Viking 1961 Convertible, 2009 WL 2775292 (S.D.N.Y. Aug. 24, 2009); United States v. Nicolo, 597 F. Supp. 2 d 342 (W.D.N.Y. 2009); United States v. Faq, 2009 WL 3811826 (S.D.N.Y. Feb. 2, 2009); United States v. Madden, 2009 WL 2905249 (S.D.N.Y. Aug. 19, 2009); United States v. Lyttle, 2009 WL 4698471 (W.D.N.Y. Sept. 26, 2009); United States v. Luis Felipe Moreno Godoy, 2009 WL700852 (S.D.N.Y. Feb. 23, 2009); United States v. al Huraibi, 2009 WL 1449012 (W.D.N.Y. May 21, 2009); United States v. Guastaferro, 2009 U.S. Dist. LEXIS 119108 (W.D. N.Y. December 20, 2009); United States v. Dreier, 2009 WL 733897 (S.D.N.Y. Mar. 17, 2009); United States v. Coren, 2009 WL 649801 (E.D.N.Y. Feb 25, 2009); United States v. Clement, 2009 WL 5820262 (E.D.N.Y. Sept. 30, 2009); United States v. Doherty, 2009 WL 2954315 (E.D.N.Y. Apr. 16, 2009); United States v. Capoccia, 2009 WL 2601426 (D. Vt. Aug. 19, 2009); United States v. Byors, 586 F.3d 222 (2d Cir. 2009); United States v. Anderson, 2009 WL 5262172 (W.D.N.Y. Aug. 31, 2009); United States v. Andersen, 2009 WL 1743931 (N.D.N.Y. Jun. 18, 2009); United States v. Vilar, 2009 WL 5000238 (S.D.N.Y. Oct. 2, 2009); United States v. \$829,422.42 in U.S. Currency, 2009 WL 1743753 (D. Conn. Jun. 18, 2009); United States v. Deposit at Man Financial, Inc., 2009 U.S. Dist. LEXIS 51910 (S.D.N.Y. June 16, 2009); United States v. Dispascali, 2009 WL 2448196 (S.D.N.Y. 2009); United States v. Queri, 2009 WL 6506462 (N.D.N.Y. Nov. 18, 2009); United States v. Rodriguez-Olivera, 2009 WL 5438586 (E.D.N.Y. Aug. 20, 2009); United States v. Rennick, 2009 WL 6528377 (S.D.N.Y. Aug. 5, 2009); United States v. Roberts , 2009 WL 2040991 (E.D.N.Y. May 29, 2009); United States v. Bourke, 2009 WL 3149538 (S.D.N.Y. May 26, 2009); United States v. Madoff, 2009 WL 772903 (S.D.N.Y. Mar. $10,2009)$.
} 


\section{B. Data Recording Procedure}

The study considered three primary measures: 1) predicate crime (the underlying offense that was the source of the illicit funds); 2) the transaction used to launder funds; and 3) level of lawyer involvement. The cases were coded for underlying predicate crime according to the following categories: drug trafficking, other blue collar, white collar (including fraud and embezzlement), financing of terrorism, bribery/corruption, organized crime/racketeering, and illegal gambling. ${ }^{120}$ The cases were also coded for the transactions used to launder money according to the following categories: real estate purchase or sale; purchase of other movable, durable goods (such as cars, yachts, and gold); use of lawyer trust account; wire transfers; use of monetary instruments; other bank transactions; creation of shell corporation or trust; buying and selling of companies; funneling funds through an operating business; delivery of bulk currency; hawala; and "other.",121

Finally, level of lawyer involvement in the transaction was coded as " 0 " if no lawyer involvement was apparent from the case documents, " 1 " if a lawyer was specifically mentioned in the case documents as facilitating the transaction, " 1.5 " if a lawyer was specifically mentioned in the case and charged as a the defendant in the case,

\footnotetext{
${ }^{120}$ The five basic categories usually cited by enforcement organizations: drug trafficking, other "blue collar" crimes, white-collar crimes (such as fraud and embezzlement), bribery and corruption (involving U.S. and/or foreign officials), and the financing of terrorism. See REUTER \& TrumAn, supra note 15, at 4. See also The U.S. Treasury Department's 2007 Money Laundering Strategy, available at http://www.ustreas.gov/press/releases/docs/nmls.pdf.

${ }^{121}$ These category transaction types correspond to the methods generally cited by the FATF and the Treasury Department as the most common methods for laundering illicit funds. For a complete description of each transaction type and a compilation of statistics on these transaction types, see REUTER \& TRUMAN, supra note 15 , at $32-33$.
} 
" 2 " if a lawyer was not mentioned, but is legally required for transaction; ${ }^{122}$ and " 3 " if a

lawyer was not mentioned or required, but, given the complexity of the transaction

involved, a high likelihood of lawyer involvement was present.

\section{Results Analyses}

In order to determine whether lawyers were involved in a significant number of commercial transactions that served to launder illicit funds, the cases considered for this study were investigated through frequency and percentages. The categories considered were predicate crime, transaction used to launder money, and level of lawyer involvement. The frequency and percentages of cases as measured through these three measures are presented in Tables 1 to 5 .

\section{Predicate Crimes}

Table 1 presents the frequency and percentages of the predicate crimes of the cases considered for this study. Twenty-seven cases involved white collar crimes, thirteen cases involved drug trafficking, three cases involved bribery or corruption; three cases involved illegal gambling; two cases involved organized crime; two cases involved terrorism financing; and one involved other blue collar crimes.

\footnotetext{
${ }^{122}$ Each of the real estate transactions in the sample set took place in New York and therefore required attorney facilitation. As discussed in a recent legislative report prepared at the request of the Connecticut General Assembly, "[s]tates take a variety of approaches to attorney involvement in real estate closings, settlements, and refinancing. Whether an attorney must be present at a closing is typically a question of whether a non-attorney conducting a closing would be engaged in the unauthorized practice of law." http://www.cga.ct.gov/2009/rpt/2009-R-0448.htm. Under New York law, only an attorney who "has been regularly admitted to practice, as an attorney or counselor, in the courts of record in the state" may "directly or indirectly, compensation ... for preparing deeds, mortgages, assignments, discharges, leases or any other instruments affecting real estate.” (N. Y. Jud. Law § 484). In June 2009, a New York Appellate Court censured an attorney for professional misconduct for violating this law, holding that the attorney "committed professional misconduct by forming a corporation with a non-lawyer for the provision of real estate closing services, as non-attorney employees prepared the deeds used at closing. Garas v. Grievance Comm. of the Eighth Judicial Dist., 65 A.D. 3d 164 (N. Y. App. Div. 2009)). The court noted that "[a]lthough [the attorney] reviewed the prepared deeds and title searches, he had no involvement in the day-to-day operations of [the company], and he exercised no supervisory authority over the nonlawyer member." Id. at 165.
} 
Table 1: Frequency and Percentages of Predicate Crimes

\begin{tabular}{lcc}
\hline \multicolumn{1}{c}{ Predicate Crime } & Frequency & Percent \\
\hline Drug Trafficking & 13 & 32.5 \\
Other Blue Collar & 1 & 2.5 \\
White Collar & 27 & 67.5 \\
Terrorism Financing & 2 & 5 \\
Bribery/Corruption & 3 & 7.5 \\
Organized Crime & 2 & 5 \\
Illegal Gambling & 3 & 7.5 \\
\hline
\end{tabular}

\section{Transactions Employed}

Table 2 presents the frequency and percentages of the transactions used to launder illicit funds. The transactions identified for this analysis were real estate, other durable purchased goods, lawyer trust account, wire transfers, monetary instruments, other bank transactions, shell corporations, buying and selling of companies, funneling funds through an operating business, delivery of bulk currency, hawala, and "other." Among these, the majority of the transactions were classified as bank transactions through wire transfers, monetary instruments, and/or other bank transactions $(n=36,90 \%)$. Nine cases involved shell companies, and eight involved funneling money through an operating business. There were no observed instances of buying and selling companies, hawala, or "other."

Table 2: Frequency and Percentages of Transaction used to Launder Money

\begin{tabular}{lcc}
\hline Transaction used to Launder Money & & \\
& Frequency & Percent \\
\hline Real Estate & 4 & 10 \\
Purchased Goods & 6 & 15 \\
Lawyer Trust Account & 3 & 7.5 \\
Wire Transfers & 23 & 57.5 \\
Monetary Instruments & 23 & 57.5
\end{tabular}




\begin{tabular}{lcc} 
Other Bank Transactions & 13 & 32.5 \\
Shell Corporations & 9 & 22.5 \\
Buying and Selling of Companies & 0 & 0 \\
Funnelled through an Operating & 8 & 20 \\
Business & & \\
Delivery of Bulk Currency & 2 & 5 \\
Hawala & 0 & 0 \\
Other & 0 & 0 \\
\hline
\end{tabular}

\section{Aggregate Lawyer Involvement}

Of the forty cases in the final data set, ten cases presented evidence of some level of lawyer involvement in the transaction employed to launder the illicit funds. ${ }^{124}$ Of the ten cases with lawyer involvement, four of the cases involved lawyer self-directed frauds wherein the lawyer engaged in a fraudulent scheme and laundered the illicit funds through wire transfers, lawyer trust accounts, or real estate. ${ }^{125}$ These were the only cases in the sample in which a lawyer was charged with a crime as the result of involvement in the case. Table 3 presents the frequency and percentages of lawyer involvement.

\footnotetext{
${ }^{124}$ Wright, 2009 WL 6040567 (money laundered through irrevocable trust creation); Bennett, 2009 WL 3614613 (real estate); Follieri, 2009 U.S.Dist LEXIS 3783 (real estate); Dreier, 2009 WL 733897 (lawyer self-directed fraud; money laundered through wire transfers); Coren, 2009 WL 649801 (lawyer selfdirected fraud; money laundered through wire transfers); Clement, 2009 WL 5820262 (lawyer specifically mentioned as facilitating real estate transaction used to launder funds and use of lawyer trust account); Capoccia, 2009 WL 2601426 (lawyer self-directed scheme; money laundered through lawyer trust account); Anderson, 2009 WL 5262172 (drug trafficking case; money laundered through real estate); Andersen, 2009 WL 1743931 (lawyer specifically mentioned as facilitating real estate transaction used to launder funds and use of lawyer trust account); Queri, 2009 WL 6506462 (lawyer self-directed scheme; money laundered through lawyer trust account and real estate).
}

${ }^{125}$ Dreier, 2009 WL 733897; Coren,2009 WL 649801; Capoccia, 2009 WL 2601426; Queri, 2009 WL 6506462. 
Table 3: Aggregate Frequency and Percentages of Lawyer Involvement

\begin{tabular}{lcc}
\hline \multicolumn{1}{c}{ Lawyer Involvement } & Frequency & Percent \\
\hline Total number of cases & 40 & 100 \\
No lawyer involvement & 30 & 75 \\
Lawyer Self-Directed Scheme; lawyer is a defendant in the case & 4 & 10 \\
Lawyer mentioned in case as facilitating or present at transaction, & 2 & 5 \\
but not charged as defendant & 3 & 7.5 \\
Lawyer not mentioned, but required for transaction & 1 & 2.5 \\
Lawyer not mentioned or required, but high likelihood of & & \\
involvement & 10 & 25 \\
Total Lawyer Involvement of any kind & & \\
\hline
\end{tabular}

\section{Non-Self-Directed Lawyer Involvement}

Six cases contained evidence of non-self directed lawyer involvement in the transactions employed to launder the illicit funds. In five of the cases, the money was laundered through the purchase of real estate. ${ }^{126}$ Two of the five cases made direct reference to attorney involvement in the transaction used to facilitate the money laundering, and in both cases, the transaction was accomplished through the purchase of real estate accompanied by the use of a lawyer trust account. ${ }^{127}$ In the remaining case, the illicit funds were laundered through the creation of an irrevocable trust. ${ }^{128}$ While the use of a lawyer was not mentioned in that case, a strong likelihood of lawyer involvement was noted. ${ }^{129}$ Cross-tab analysis ${ }^{130}$ is employed in Table 4 to analyze lawyer involvement in the three types of occurring transactions.

\footnotetext{
${ }^{126}$ Bennett, 2009 WL 3614613; Follieri, 2009 U.S.Dist LEXIS 3783; Clement, 2009 WL 5820262;

Anderson, 2009 WL 5262172; Andersen, 2009 WL 1743931.

${ }^{127}$ Clement, 2009 WL 5820262; Andersen, 2009 WL 1743931.

${ }^{128}$ Wright, 2009 WL 6040567; Bennett, 2009 WL 3614613.

${ }^{129}$ See id.
} 
Table 4: Crosstab Analysis for Non-Self-Directed Lawyer Involvement

\begin{tabular}{lccc}
\hline \multicolumn{1}{c}{ Lawyer Involvement } & $\begin{array}{c}\text { Lawyer } \\
\text { Real } \\
\text { Estate }\end{array}$ & $\begin{array}{c}\text { Shell } \\
\text { Account }\end{array}$ & $\begin{array}{c}\text { Companies } \\
\text { Number of cases with non-self-directed lawyer }\end{array}$ \\
$\begin{array}{l}\text { involvement } \\
\text { Lawyer mentioned in case as facilitating or present } \\
\text { at transaction, but not charged as defendant }\end{array}$ & 2 & 2 & 0 \\
$\begin{array}{l}\text { Lawyer not mentioned, but required for transaction } \\
\text { Lawyer not mentioned or required, but high }\end{array}$ & 3 & 0 & 0 \\
likelihood of involvement & 0 & 0 & 2
\end{tabular}

\section{Predicate Crimes}

The predicate crimes in nine of the ten cases with lawyer involvement were white collar crimes, including schemes based in fraud and embezzlement. Moreover, as observed in Table 5, all of the lawyer-self-directed schemes involved white collar crimes, and five of the six non-lawyer self-directed schemes involved white collar crimes. Crosstab Analysis for Predicate Crime and Lawyer Involvement

\begin{tabular}{|c|c|c|}
\hline & $\begin{array}{l}\text { Lawyer Self-Directed } \\
\text { Scheme }\end{array}$ & $\begin{array}{c}\text { Non-Self-Directed } \\
\text { Lawyer Involvement }\end{array}$ \\
\hline Drug Trafficking & 0 & 1 \\
\hline White Collar & 4 & 5 \\
\hline
\end{tabular}

\section{Implications for Attorney Gatekeeping Role}

This Section first offers implications of the data gathered from the Second Circuit study. It then proposes that the ABA should require that lawyers in the United States certify that they complied with the ABA's Good Practices in order to reduce instances in which a client might use an attorney's services to launder money without her knowledge.

\footnotetext{
${ }^{130}$ Cross-tab analysis is the process of creating a contingency table from the multivariate frequency distribution of categorical variables.
} 


\section{A. Study Results}

Despite the limited size of the study, certain conclusions emerge. A statistical analysis revealed that lawyers facilitated money laundering, both wittingly and unwittingly, in twenty-five percent of the cases examined. Of that subset, forty percent of those cases involved lawyer self-directed schemes wherein the lawyer engaged in a fraudulent scheme to generate illicit funds and effectuated the transactions to launder those ill-gotten gains. The legal profession is not immune to intentional wrongdoing, and existing money laundering laws account for such criminal conduct, as evidenced in the data set. ${ }^{131}$ Each of the attorneys engaged in such intentional wrongdoing was indicted under the money laundering statutes. ${ }^{132}$ Fifteen percent of the total sample of cases involved unwitting lawyer involvement in the transactions used to launder illicit funds. Of those cases, five of the six involved the purchase or sale of real estate, with two cases containing documents that specifically mentioned the use of a lawyer trust account as well. Given that the funds to be used for the purchase and those that result from the sale of real estate often pass through the closing attorney's client trust account, this type of transaction is particularly susceptible to unwitting lawyer involvement.

\footnotetext{
${ }^{131}$ There are, of course, instances in which individuals who are caught (and charged) with money laundering actually might make less use of counsel than those not caught. For example, attorneys might be aiding clients evade criminal proceedings. It is impossible, however, to develop data to study instances of this phenomenon. If lawyers are aiding clients in evading criminal charges of money laundering without some type of gatekeeping currently in place, it is not likely that new regulations would lead the attorney not to engage in similar illegal action. Rather, law enforcement would have to enforce current criminal statutes against those attorneys.

${ }^{132}$ Dreier, 2009 WL 733897; Coren, 2009 WL 649801; Capoccia, 2009 WL 2601426; Queri, 2009 WL 6506462.
} 
Furthermore, due to the breadth of the money laundering statutes, any wiring out of the account of the tainted money may lead to a charge of money laundering. ${ }^{133}$ In several of the cases in the study, the borrower was involved in a mortgage fraud scheme as the underlying predicate crime, and money laundering was added as an additional charge once the money was wired out of the lawyer trust account. ${ }^{134}$ In others, the real estate purchased was placed in the name of a third party to obscure the criminal purchaser's true ownership of the asset. ${ }^{135}$ In each of these cases, the lawyer may not have inquired about, or verified through tax returns, the source of the purchaser's income and may not have verified the occupancy of the property in question. The "touch the money test"136 adopted by the American Bar Association in its Good Practices, which advises lawyers to conduct heightened due diligence regarding the source and legitimacy of the funds if a lawyer handles the money, is implicated each time a lawyer handles the funds for a real estate transaction. The results of this study support the need for such special attention for lawyer involvement in real estate transactions. On the other hand, only one case in the study was coded as potentially involving an unwitting lawyer in the creation of a legal entity, and it was the creation of an irrevocable trust, rather than the creation of a shell corporation. Additionally, not only did no cases with lawyer involvement involve the buying and selling of companies, but none of the money laundering cases in the sample involved such transactions. These results indicate that the typical typology of money laundering through unwitting lawyer participation in the

\footnotetext{
${ }^{133}$ See, e.g., Bennett, 2009 WL 3614613.

${ }^{134}$ See Andersen, 2009 WL 1743931; Clement, 2009 WL 5820262.

${ }^{135}$ See Anderson, 2009 WL 5262172; Follieri, 2009 U.S. Dist. LEXIS 3783.

${ }^{136}$ See Good Practices at 22, para. 3.1.
} 
transaction does not include the purchase or sale of legal entities, nor the creation of shell companies. As creation, purchase, and sale of legal entities constitutes the majority of a transactional lawyer's practice, regulatory requirements affecting these specific activities would carry a burden that may not be offset by any increase in money laundering or financing of terrorism detection. Additionally, the anti-money laundering rationale for pending legislation that would require lawyers to gather and report beneficial owner information for all legal entities the lawyer creates may be misplaced. ${ }^{137}$ Finally, the predicate crimes which led to lawyer involvement in a transaction to launder the money were overwhelmingly white collar crimes.

One can use the data from the Second Circuit to address the ABA's concerns regarding requiring transactional lawyers to engage in heightened due diligence requirements based on its concerns that the regulations will have a negative impact on aspects of the lawyer-client relationship and Constitutional arguments based on the Sixth and Tenth Amendments. To that end, this article proposes that a lawyer should certify that she followed the ABA's Good Practices to determine if she reasonably believed that the client did not present a risk of abusing the lawyer's services to launder money. The proposal attempts to strike a balance between Congressional concern that federal

\footnotetext{
${ }^{137}$ Similar beneficial ownership information gathering and reporting requirements were proposed by the U.S. Congress as part of bills aimed at suppressing tax evasion. See, e.g., Stop Tax Haven Abuse Act, S. 506 and H.R. 1265 (2009), S. 681, $110^{\text {th }}$ Cong. (2007). Although tax evasion is not a predicate crime to money laundering, the rationale for Congress's failed attempts to mandate beneficial ownership information gathering and reporting in the past has been recovery of lost tax revenue (personal income can be obscured through the use of shell companies). For a thorough discussion of the relationship between Congress's attempts to mandate beneficial ownership information gathering and reporting for tax recovery purposes, as well as through its new anti-money laundering rationale, see Richard K. Gordon, On the Use and Abuse of Standards for Law: Global Governance and Offshore Financial Centers, 88 N.C. L. REV. 501 (2010). For a cost-benefit analysis of legislation that would impose beneficial ownership information gathering and reporting, see J.W. Verret, Terrorism Finance, Business Associations, and the Incorporation Transparency Act, 70 LA. L. REV. 857 (2010).
} 
regulation is necessary for FATF compliance and the ABA's current voluntary approach to due diligence requirements.

\section{B. Certification Requirement}

The ABA hopes that by implementing the Good Practices, lawyers will perform some form of due diligence voluntarily in order to ensure that their services are not used to launder money. For example, Kevin Shepherd maintains that if lawyers "embrace the Good Practices Guidance and implement it in their client intake, CDD, and on-going client monitoring process" they can "signal to FATF and federal regulators and legislators that the legal profession can take steps to ensure that the services they provide will not promote of facilitate money laundering or terrorist financing, thereby obviating the need for a federally imposed, rules-based AML/CFT regime." ${ }^{\prime 38}$ Mr. Shepherd recognizes the dangers to "the attorney-client relationship, including the attorney-client privilege and the duty of client confidentiality" associated with the enactment of a federal legislation. ${ }^{139}$ To combat these evils, he maintains that voluntary regulatory steps can and will signal to federal regulators that further oversight of the legal community is unnecessary. The voluntary aspect of the Good Practices, however, only provides lawyers with an option to comply. These guidelines lack any type of requirement, which will likely lead to federal intervention in order to mandate compliance.

The ABA's concerns regarding attorney-client relationships and Constitutional abridgments are warranted and valid arguments against federal involvement in this area, but a failure to act will, in all likelihood, lead Congress to pass federal legislation that

\footnotetext{
${ }^{138}$ Kevin L. Shepherd, The Gatekeeper Initiative and the Risk-Based Approach to Client Due Diligence: The Imperative for Voluntary Good Practices Guidance For U.S. Lawyers, 2010 J. PROF’L. LAWYER 83, 102 (2010).

${ }^{139} I d$.
} 
mandates attorneys conform to certain provisions of the FATF. In order to avoid federal intervention, this article maintains that the $\mathrm{ABA}$ should recommend that attorneys certify that they complied with the ABA's Good Practices. This proposal offers a middle ground between the two schools of thought regarding attorneys acting as gatekeepers for FATF enforcement. On the one hand, calls for federal involvement seem overstated.

First, any regulations that would require attorneys to report to law enforcement clients who potentially are engaged in money laundering would have a negative impact on aspects of the lawyer-client relationship, including confidentiality, the attorney-client privilege, lawyer independence, and the attorney's duty of loyalty. Additionally, the Second Circuit study does not appear to demonstrate an ultimate need for lawyers to act as agents of the government by filing SARs with a federal entity. On the other hand, however, the voluntary, risk-based guidance for the legal profession, does not go far enough to either demand that lawyers attempt to prevent money laundering, nor incentivize that attorneys investigate a client's risk potential. As a result, this article maintains that the ABA should be cognizant of Congress's desire to conform with the FATF's requirements because the political landscape, which involves fighting terrorism and money laundering in the international community, makes it unlikely that the United States "will want to be expelled from" the FATF. ${ }^{140}$

\section{Certification Framework}

Certification offers a self-regulating procedure for attorneys to act as gatekeepers in order to prevent clients from using a lawyer's services to launder money without sacrificing the ABA's interest in attorney-client relationships and Constitutional

\footnotetext{
${ }^{140}$ Terry, supra note 86.
} 
protections. Generally, certification is a written opinion by an attorney for the services that she provides. ${ }^{141}$ The opinions are usually "narrowly drawn and addressed" and they tend to provide "negative assurances." "142 The certification usually maintains that an attorney "conducted investigations [she] deemed necessary and that nothing came to [her] attention that would prevent [her] from opining that the transaction is lawful and that disclosure is in conformity with regulations." ${ }^{143}$ Although the law does not currently require lawyers to provide this type of investigation and certification for lawyers participating in securities-related matters, ${ }^{144}$ Professor Paul Coffee, Jr. offers a practical example of how lawyers can act as gatekeepers through certification requirements and the positive benefits of such a regime.

Professor Coffee addressed the issue of attorney certification in the context of Section 307 of the Sarbanes Oxley Act. ${ }^{145}$ He argues "that securities attorneys can and do perform a limited 'gatekeeping' function and that imposing such obligations on attorneys should neither chill socially desirable client communications nor reduce the attorney's influence over the client (and probably will increase that leverage)."146 Rather than simply adopting noisy withdrawal procedures, he "propose[d] both limited

\footnotetext{
${ }^{141}$ See Cunningham, supra note 6 at 366. In his article, Professor Cunningham details attorney certification in the context of securities-related matters. He maintains that "[a] common example [of certification] occurs when an underwriting agreement conditions that underwriter's duty on receiving an opinion from issuer's counsel concerning the legality of the transaction and compliance, as to form, with federal securities regulations." Id.

${ }^{142} I d$.

${ }^{143} I d$. at 367.

${ }^{144}$ See id. at 368 .

${ }^{145}$ Coffee, Jr., supra note 6.

${ }^{146} I d$. at 1293.
} 
certification and independence standards." ${ }^{147}$ In balancing the competing interests of publicly filed documents on behalf of corporations on the one hand, with the duty of loyalty to clients on the other, Professor Coffee suggests that the SEC should impose a due diligence obligation, an independence requirement, and an attorney certification requirement under the Sarbanes Oxley regulatory regime. ${ }^{148}$

Professor Coffee proposes criteria that will allow lawyers to be instituted as gatekeepers under Sarbanes Oxley. First, he suggests what he considers the least controversial proposal, that securities lawyers "should perform some due diligence in preparing prospectuses or other disclosure documents." $" 149$ In other words, an attorney should go beyond merely relying on a "client's assertions," and instead, should investigate the veracity of a client's personal and professional information in conformity with the rules of professional conduct. ${ }^{150}$ Next, he argues that lawyers should be subjected to a certification requirement to guarantee that all documents that lawyers file face a "reasonable due diligence examination" by an attorney. ${ }^{151}$ This procedure could be used to require an attorney to certify that she "believed adequate disclosure had been made after making such inquiry that the attorney reasonably believed appropriate in the

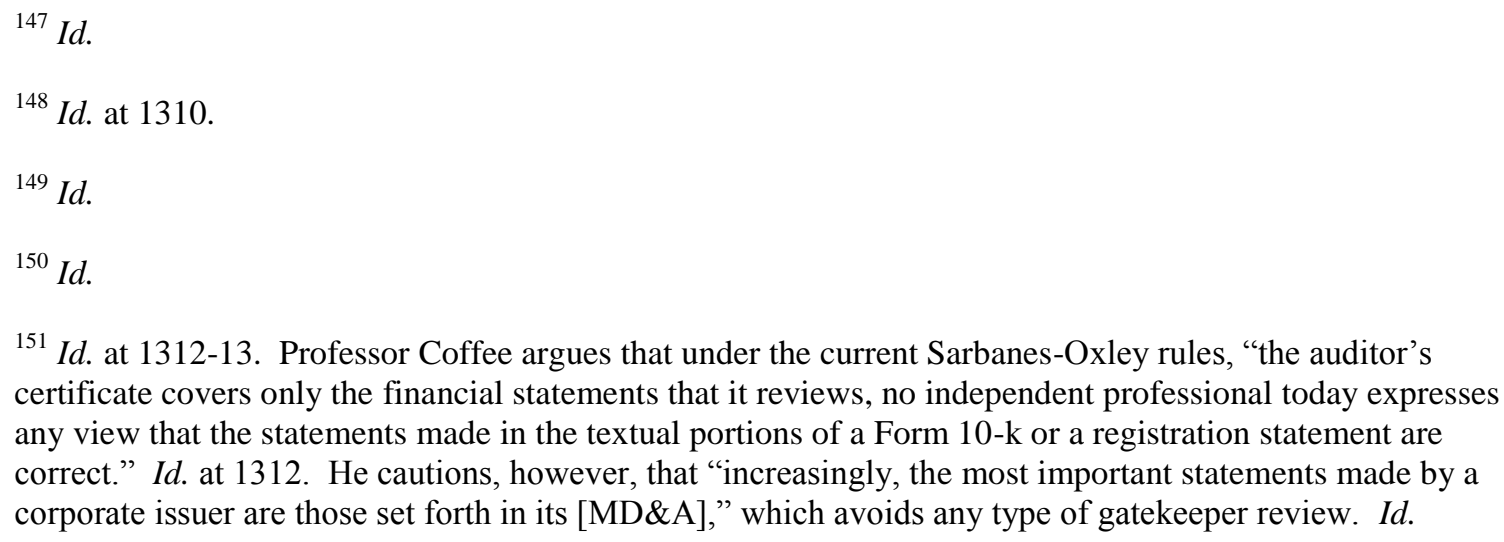


circumstances." 152 This step, then, would couple the certification requirement with the due diligence requirement. This approach offers a good framework from which the ABA could build a mandatory certification requirement to ensure that lawyers perform a client risk-assessment and heightened due diligence required by the Good Practices.

\section{Application}

This article maintains that the ABA should initiate a certification requirement based on the ABA's Good Practices. Lawyers would rely on the risk-based guidance and factors that should initiate further investigation if triggered, to ensure that attorneys take the steps necessary to prevent them from becoming unknowing conduits for clients to launder money. In this context, lawyer certification would have three components. First, as maintained in the Good Practices, an attorney would identify if she is performing one of the three Specified Activities including (1) real estate closings and settlements; (2) company formation; and (3) handling client funds through lawyer trust accounts. If she is, she would perform her client due diligence requirement including verifying the client's identity, employment background, and other basic information. Second, the attorney would investigate if the client triggers either country/geographic risk, service risk, and/or client risk. ${ }^{153}$ She would investigate these factors on a sliding scale where the various risk factors would either increase or decrease risks posed by each client.

Finally, upon finishing this investigation, the attorney would certify, "after making such inquiry that the attorney reasonably believed appropriate in the

\footnotetext{
${ }^{152}$ Id. at 1315 .

${ }^{153}$ See, supra notes 95-113 and accompanying text.
} 
circumstances" $" 154$ that she believed that the client did not present a risk of abusing the lawyer's services to launder money. If, on the other hand, the lawyer found that the client presented an unacceptable risk, she should decline or withdraw from representing the client. For example, under current ethical rules, a lawyer may not assist a client in conduct that she knows is criminal or fraudulent. ${ }^{155}$ A lawyer who believes her services are being used in the furtherance of a crime or fraud is obligated to withdraw from the representation, ${ }^{156}$ and a lawyer may disclose an individual client's wrongdoing if her services were used in perpetuating the crime or fraud and she believes the disclosure is necessary to prevent, mitigate, or rectify, financial harm to another. ${ }^{157}$ This approach would couple a certification requirement with the voluntary due diligence approach practiced by the ABA.

The proposal seeks to strike a balance between Congressional concern that federal regulation is necessary for FATF compliance and the ABA's current voluntary approach to due diligence requirements. This approach will allow the bar, and not federal regulators, to hold lawyers accountable to ensure that necessary due diligence steps are

\footnotetext{
${ }^{154}$ Coffee, supra note 6 at 1315 . Of course, inherent in any regulatory scheme that requires a certification requirement is the desire for those regulated to know what steps would be considered "reasonably appropriate" in a situation. The ABA's approach in its Good Practices offers a practical approach on which a lawyer can rely. The ABA views a lawyer's approach to due diligence as "sliding scale where one or more ... variable factors may increase or decrease the perceived risk posed by a particular client or type of work." Good Practices at 38.

${ }^{155} \mathrm{See}$ Model Rules of Professional Responsibility 1.2 (d).

${ }^{156}$ See Model Rule of Professional Responsibility 1.16(a). In some instances, where the attorney's services have been used in furtherance of the client's fraud or crime, and a third party is relying upon a statement by the attorney, the attorney may be required to withdraw the statement. See Model Rules of Professional Responsibility 4.1(b).

${ }^{157}$ See Model Rule of Professional Responsibility 1.6 (b)(2) and (3). Where the lawyer's client is an entity, the lawyer is required to report certain client wrongdoing to the highest authority in the organization, and if action is not taken, the attorney may disclose the wrongdoing to authorities outside of the organization. See Model Rule of Professional Responsibility 1.13.
} 
taken if clients present risk factors that indicate they may use an attorney's service to launder money. Additionally, on a basic level, it requires that attorneys are held accountable for assessing the risks that their clients present for engaging in money laundering. ${ }^{158}$ Finally, as the Second Circuit study indicates, clients have used lawyer's services to launder money without the lawyer's knowledge in multiple instances.

Although this requirement cannot guarantee preventing all instances in which clients use an unknowing attorney's services to launder money, it would be a first step in reducing that number closer to zero.

\section{Counter Arguments Investigated}

Of course, as with any proposal, certain limitations apply to requiring that lawyers certify that they followed the ABA's Good Practice. In the instant case, two arise: (1) what, exactly, can an attorney be expected to certify and (2) mandating that a lawyer perform the certification requirement may be burdensome to a profession that is already regulated. This section addresses each in turn.

Professor Coffee recognizes that the certification requirement, at least in the context of Sarbanes-Oxley, requires one to address what a lawyer should be required to certify. ${ }^{159}$ There is likely to be real concern regarding what an attorney could be expected to certify. One must recognize that an attorney will not audit its clients and many law firms (not to mention solo practitioners) lack the resources to perform thorough due

\footnotetext{
${ }^{158}$ The attorney not only would be required to certify in documents that require official or governmental filings, but also create and maintain records in instances where a filings is not necessary for the transaction. The lawyer would need to comply with the certification requirement under the existing Model Rules of Professional Responsibility.

${ }^{159}$ See Coffee, supra note 6 at 1312.
} 
diligence of their clients in every instance. ${ }^{160}$ To combat these concerns, Professor Coffee suggests that an attorney would certify that she (1) reasonably believes, after an investigation appropriate in the circumstances "that the statements made in the document or report to be true and correct in all material respects" and that she (2) "is not aware of any additional material information whose disclosure is necessary in order to make the statements made, in the light of the circumstances under which they were made, not misleading." ${ }^{161}$ Such certifications requirements are also appropriate in the FATF context and offer a framework for attorneys to proceed under the Good Practices.

For example, the Good Practices provides risk criteria after investigating a client's basic background information, grouped under three main categories: geographic risk, client risk, and risk associated with the particular type of transaction. It then instructs that attorneys should engage in heightened due diligence where risk factors are present, but it permits attorneys to engage in lesser due diligence where risk factors are absent. In the certification context, lawyers would need to state in a written opinion that a client does not give the attorney cause to believe these additional risk factors.

The certification would include a statement by the attorney that she "conducted investigations [she] deemed necessary and that nothing came to [her] attention that would prevent [her] from opining that the transaction is lawful and that disclosure is in conformity with regulations." ${ }^{\prime 162}$ For example, if, after performing the initial verification of a client's identity, if the lawyer knows who the beneficial owner is, or if the lawyer has

\footnotetext{
${ }^{160} I d$.

${ }^{161} I d$.

${ }^{162}$ Cunningham, supra note 6 at 367.
} 
worked for the client for numerous years and knows from prior experience that the client does not alert the lawyer to any risks, the lawyer would certify that she performed the due diligence required in the situation. If, however, the client triggered either country/geographic risk, service risk, and/or client risk the client would have to investigate further the risks of the client in conformity with the ABA's Good Practice based on a sliding scale where the various risk factors would either increase or decrease the lawyer's perceived risk of her client. After further investigation, the attorney could either certify that the client does not pose a risk, she could refuse the take the individual as a client, or she could withdraw from service if she has acted in a representative capacity already.

An additional criticism of certification requirements is that it places unnecessary regulations on attorneys. This argument is formulated on two levels. First, critics maintain that "blanket mandates may demand more than is necessary. Not all enterprises require comprehensive gatekeeper vetting." 163 In other words, rather than directing attorneys to act, regulations and laws in place will deter lawyers from engaging in activities that they know or reasonably could know are improper for the legal profession. Second, not only are those regulations unnecessary, but, critics maintain, they also "might demand more than is possible. Fraud and other sources of misreporting can be hidden in ways that no professional could discover." "164 The argument maintains that despite an individual's best efforts, certain instances of illegal activity cannot be detected by even the most diligent attorney.

\footnotetext{
${ }^{163} I d$. at 368 .

${ }^{164}$ Id. at 368-69. Professor Cunningham also cautions that "[r]isks of error can be so high that the expected costs to the professionals exceed the price that they could charge for backstopping their opinions." Id. at 369.
} 
While, in certain instances additional regulation may be unnecessary insofar as lawyers already operate within an established regulatory regime, a failure to require attorneys to act as limited gatekeepers could result in rule-making by Treasury that may impose federal regulations on the profession requiring it to act as gatekeepers for the federal system. Although blanket mandates may be unnecessary, the approach proposed here is a tailored certification requirement that seeks to ensure that all attorneys participate in the Good Practices, which are currently voluntary. Moreover, as in any activity in which an attorney engages for her client, there may be an element of deceit on behalf of the client for illicit gains. As the study of the Second Circuit indicated, fifteen percent of the total sample cases involved unwitting lawyer involvement in transactions used to launder illicit funds. Although no system of regulation is perfect, having lawyers certify that they have taken reasonable steps to ensure that clients will not engage in money laundering schemes will bring that number closer to zero.

\section{Conclusion}

The various "gatekeeping initiatives" that have been introduced through intergovernmental standard-setting organizations such as the FATF, as well as through federal legislation in the United States require that attorneys in the United States, recognize that clients may use their services to unwittingly aid in laundering money. These initiatives aim to apply the mandatory customer due diligence, record keeping, and suspicious activity reporting obligations contained in the existing anti-money laundering regime to lawyers when they conduct certain commercial transactions on behalf of their clients. Additionally, in a post-September 11th world, federal regulators do not want to be found 
non-compliant with FATF mandates, which could result in the United States being expelled from the FATF.

Although the organized bar argues against such attempts to regulate it due, in part, (1) to the lack of empirical data showing that lawyers unwittingly aid money laundering in a significant number of cases and (2) concerns that the regulations will have a negative impact on aspects of the lawyer-client relationship, this article has demonstrated that in approximately fifteen percent of the cases study, an attorney's services likely were used to launder money. As such, this article proposes a framework in which lawyers could ensure that clients are not using their services to launder money, while still protecting the vital relationship between attorneys and clients on which the legal system is based. To that end, this article maintains that lawyers should certify that they followed the ABA's Good Practices to determine if she reasonably believed that the client did not present a risk of abusing the lawyer's services to launder money. The proposal attempts to strike a balance between Congressional concern that federal regulation is necessary for FATF compliance and the ABA's current voluntary approach to due diligence requirements. Although this proposed requirement cannot guarantee that the fifteen percent of cases in the Second Circuit would be prevented, lawyer certification in this context likely will bring that percentage closer to zero. 